Supporting Information

\title{
Using Helium Pycnometry to Study the Apparent Densities of Metal-Organic Frameworks
}

Gerald E. Decker and Eric D. Bloch ${ }^{*} \dagger$

*edb@udel.edu

${ }^{\dagger}$ Department of Chemistry and Biochemistry, University of Delaware, Newark, DE 19716, United States 


\section{List of Contents}

Detailed Experimental Procedures

S3

Gas Adsorption Isotherms

S10

Defectiveness for Select UiO-66 Samples

S33

Table of Sample Densities

S34

References 


\section{Detailed Experimental Procedures}

General Considerations. All reagents were obtained from commercial vendors and used without purification. Dry N,'N-Dimethylformamide (DMF) was obtained from a solvent purification system (SPS) and stored in a brown amber bottle under $4 \AA$ sieves. Low-pressure $\mathrm{N}_{2}$ adsorption measurements were obtained on a Micromeritics Tristar II PLUS at $77 \mathrm{~K}$. Helium pycnometry measurements were carried out with a Micromeritics Accupyc II 1345.

\section{Synthesis of 2-acetyl terephthalic acid}

In a $500 \mathrm{~mL}$ round bottom flask 2-aminoterephalic acid $(5.00 \mathrm{~g}, 27.6 \mathrm{mmol})$ was combined with THF $(300 \mathrm{~mL})$. While stirring, acetyl chloride $(2.17 \mathrm{~mL}, 30.4 \mathrm{mmol})$ was added. The solution was refluxed at $80{ }^{\circ} \mathrm{C}$ overnight. The solvent was removed through reduced pressure and the powder was washed with chloroform three times. ${ }^{1} \mathrm{H}$ NMR (400 MHz, DMSO- $\left.d_{6}\right) \delta 11.0(\mathrm{~S}, 1 \mathrm{H}), 8.99(\mathrm{~s}$, $1 \mathrm{H}), 8.05(\mathrm{~d}, 1 \mathrm{H}), 7.67(\mathrm{~d}, 1 \mathrm{H}), 2.15(\mathrm{~s}, 3 \mathrm{H})$.

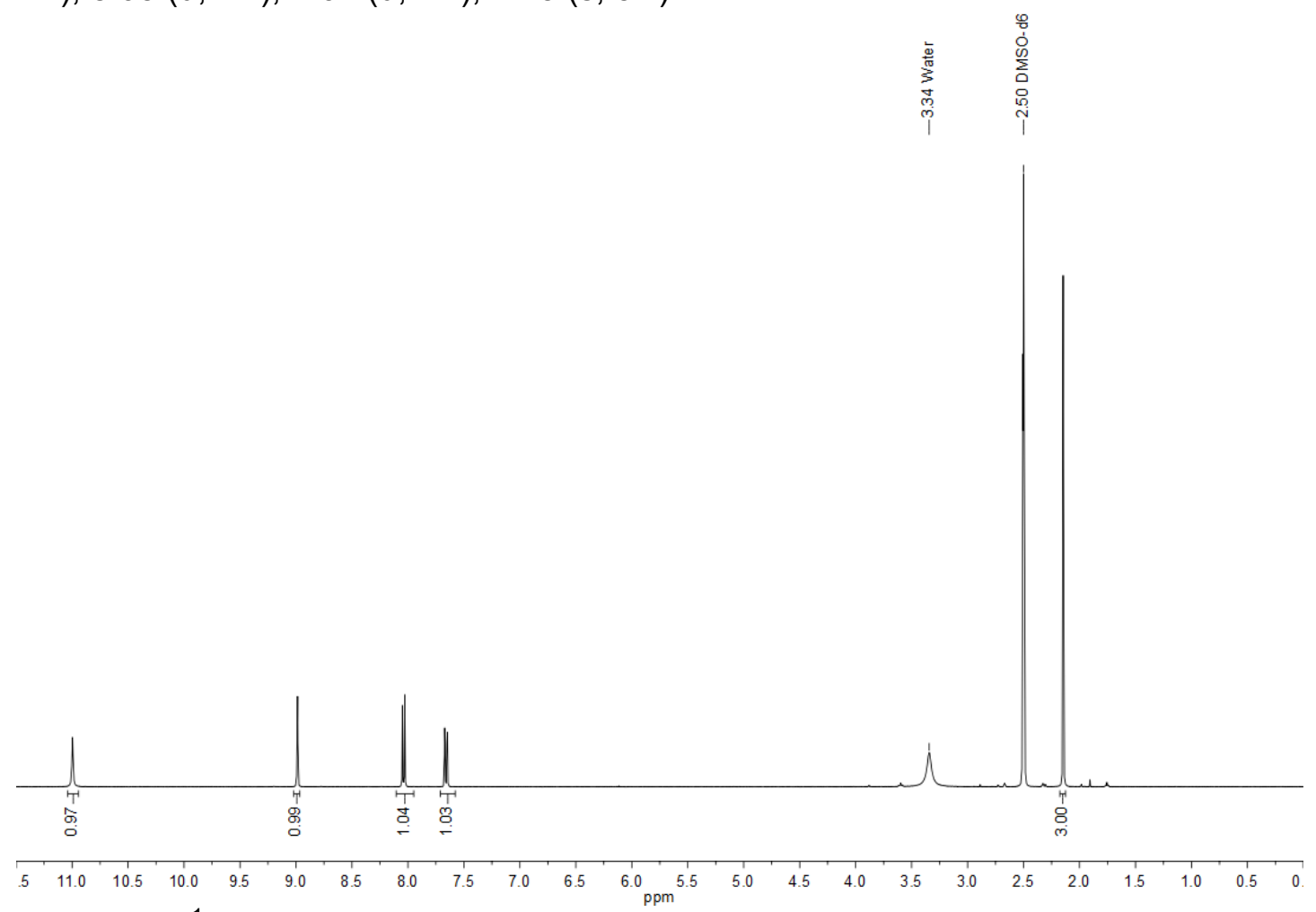

Figure S1. ${ }^{1} \mathrm{H}$ NMR analysis of 2-acetyl terephthalic acid. 


\section{Synthesis of 2-butyrl terephthalic acid}

In a $500 \mathrm{~mL}$ round bottom flask 2-aminoterephalic acid $(5.00 \mathrm{~g}, 27.6 \mathrm{mmol})$ was combined with THF $(300 \mathrm{~mL})$. While stirring, butyrl chloride $(3.15 \mathrm{~mL}, 30.4 \mathrm{mmol})$ was added. The solution was refluxed at $80^{\circ} \mathrm{C}$ overnight. The solvent was removed through reduced pressure and the powder was washed with chloroform three times. ${ }^{1} \mathrm{H}$ NMR (400 MHz, DMSO- $\left.d_{6}\right) \delta 11.06(\mathrm{~S}, 1 \mathrm{H}), 9.04(\mathrm{~s}$, $\mathrm{z} 1 \mathrm{H}), 8.05(\mathrm{~d}, 1 \mathrm{H}), 7.67(\mathrm{~d}, 1 \mathrm{H}), 2.40(\mathrm{t}, 2 \mathrm{H}), 1.65(\mathrm{~m}, 2 \mathrm{H}), 0.95(\mathrm{t}, 3 \mathrm{H})$.
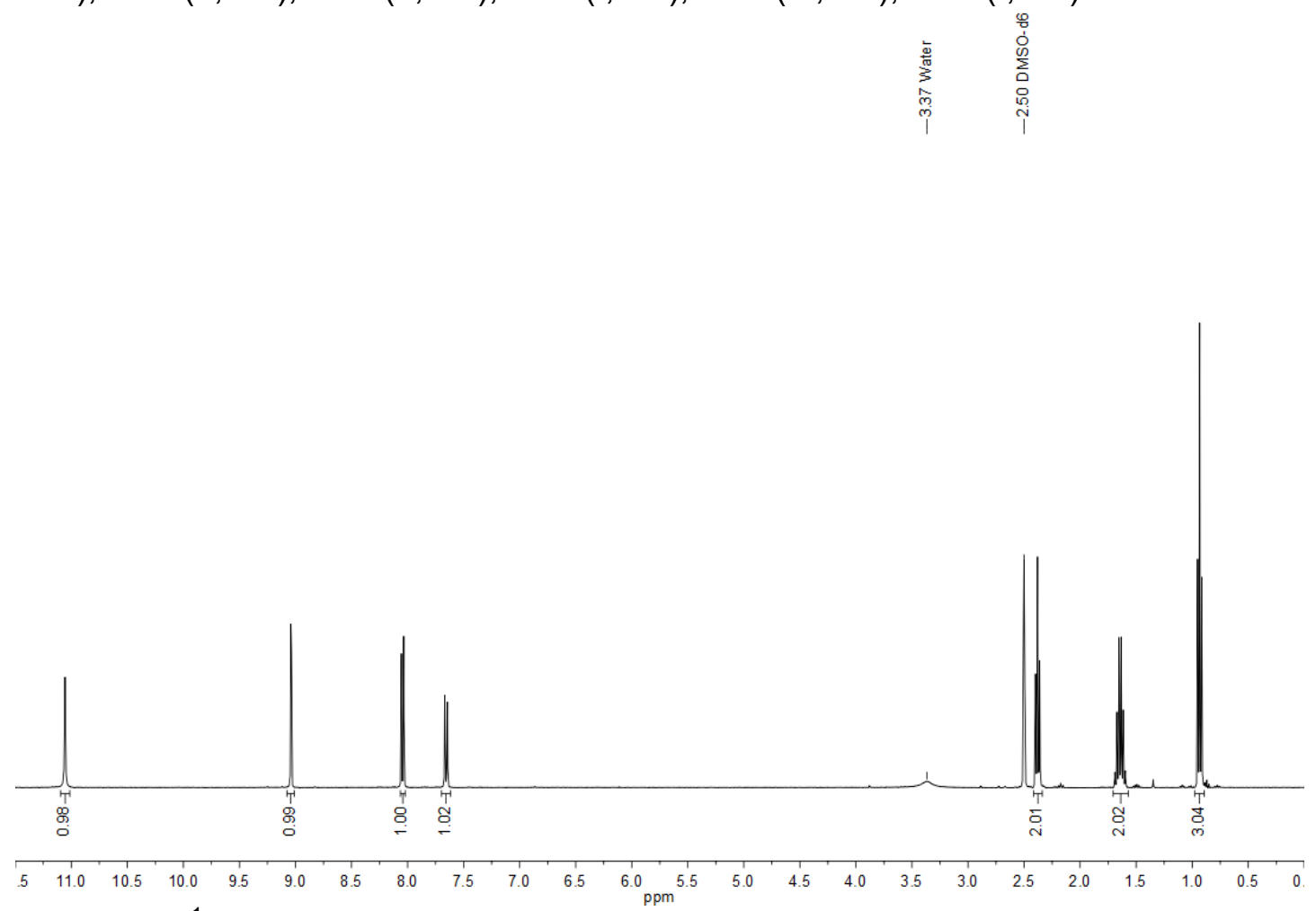

Figure S2. ${ }^{1} \mathrm{H}$ NMR analysis of 2-butyrl terephthalic acid. 


\section{Synthesis of Al-MIL-101- $\mathrm{NH}_{2}$}

The following synthesis has been prepared according to literature methods. ${ }^{1}$

\section{Synthesis of Al-MIL-53}

The following synthesis has been modified from a previously published paper. ${ }^{2} \mathrm{Al}\left(\mathrm{NO}_{3}\right)_{3} \cdot 9 \mathrm{H}_{2} \mathrm{O}$ ( $3.90 \mathrm{~g}, 18.3 \mathrm{mmol})$, terephthalic acid $(0.864 \mathrm{~g}, 5.2 \mathrm{mmol})$, and $\mathrm{H}_{2} \mathrm{O}(15 \mathrm{~mL})$ were placed in a 25 $\mathrm{mL}$ Teflon-lined steel autoclave and heated at $220{ }^{\circ} \mathrm{C}$ for 72 hours. The white powder was collected and washed three times with DMF at $65^{\circ} \mathrm{C}$ and three times with methanol. The material was then dried by vacuum activation at $300{ }^{\circ} \mathrm{C}$ for 12 hours.

\section{Synthesis of $\mathrm{Co}_{2}$ (dobdc)}

The following synthesis has been modified from a previously published paper. ${ }^{3} \mathrm{Co}\left(\mathrm{NO}_{3}\right)_{2} \bullet 6 \mathrm{H}_{2} \mathrm{O}$ $(4.754 \mathrm{~g}, 16.3 \mathrm{mmol})$ and 2,5-dihydroxyterephthalic acid $(0.964 \mathrm{~g}, 4.87 \mathrm{mmol})$ were combined with a 1:1:1 (v/v/v) solution of DMF/ethanol/ $\mathrm{H}_{2} \mathrm{O}(400 \mathrm{~mL})$ in a $500 \mathrm{~mL}$ jar. The solution was sparged with $\mathrm{N}_{2}$ for one hour then placed in a $100{ }^{\circ} \mathrm{C}$ oven for 24 hours. The solid was isolated and rinsed repeatedly with DMF, soaked three times in DMF at $120^{\circ} \mathrm{C}$ for 6 hours each, then soaked three more times in methanol at $60^{\circ} \mathrm{C}$ for 6 hours each. The material was collected then activated with flowing $\mathrm{N}_{2}$ at $180{ }^{\circ} \mathrm{C}$ for 48 hours followed by dynamic vacuum at $180{ }^{\circ} \mathrm{C}$ for 24 hours.

\section{Synthesis of $\mathrm{Co}_{2}$ (dobdc)-RT}

The following synthesis was based on a previously published paper. ${ }^{4}$ In a $250 \mathrm{~mL}$ RBF $\mathrm{Co}\left(\mathrm{NO}_{3}\right)_{2} \cdot 6 \mathrm{H}_{2} \mathrm{O}(1.589 \mathrm{~g}, 5.46 \mathrm{mmol})$ and $\mathrm{H}_{4}($ dobdc) $(336.8 \mathrm{mg}, 1.70 \mathrm{mmol})$ were dissolved in DMF (135 $\mathrm{mL})$. Then using a syringe pump a solution containing ethanol $(9 \mathrm{~mL})$, water $(9 \mathrm{~mL})$, and triethylamine $(1 \mathrm{~mL})$ was added to the reaction mixture at a rate of $120 \mathrm{~mL} /$ hour. The mixture was then allowed to stir for 2 hours at RT. The material was then transferred to $20 \mathrm{~mL}$ vials and washed with DMF at $100^{\circ} \mathrm{C}$ five times for 24 hours each, followed by three washes with methanol at $45^{\circ} \mathrm{C}$ for 24 hours each. The material was then activated with flowing $\mathrm{N}_{2}$ at $150{ }^{\circ} \mathrm{C}$ for 48 hours.

\section{Synthesis of $\mathrm{Co}_{2}(m-d o b d c)$}

The following synthesis has been modified from a previously published paper. ${ }^{5}$ Anhydrous methanol $(70 \mathrm{~mL})$ and anhydrous DMF $(130 \mathrm{~mL})$ were sparged with $\mathrm{N}_{2}$ for one hour in a $500 \mathrm{~mL}$ three-neck round-bottom flask equipped with a reflux condenser. $\mathrm{CoCl}_{2}(1.05 \mathrm{~g}, 8.08 \mathrm{mmol})$ and $\mathrm{H}_{4}\left(\mathrm{~m}\right.$-dobdc) $(0.64 \mathrm{~g}, 3.23 \mathrm{mmol})$ were added under positive $\mathrm{N}_{2}$ pressure and stirred at $120^{\circ} \mathrm{C}$ for 18 hours. The solid was isolated and washed with DMF at $70{ }^{\circ} \mathrm{C}$ for 24 hours, followed by four more washes with methanol at $70{ }^{\circ} \mathrm{C}$. The material was then activated under dynamic vacuum at $180{ }^{\circ} \mathrm{C}$ for 24 hours.

\section{Synthesis of $\mathrm{Co}_{2}$ (m-dobdc)-RT}

The following synthesis was based on a previously published paper. ${ }^{4}$ In a $250 \mathrm{~mL}$ RBF $\mathrm{Co}\left(\mathrm{NO}_{3}\right)_{2} \cdot 6 \mathrm{H}_{2} \mathrm{O}(1.589 \mathrm{~g}, 5.46 \mathrm{mmol})$ and $\mathrm{H}_{4}(m$-dobdc) $(336.8 \mathrm{mg}, 1.70 \mathrm{mmol})$ were dissolved in DMF (135 $\mathrm{mL})$. Then using a syringe pump a solution containing ethanol $(9 \mathrm{~mL})$, water $(9 \mathrm{~mL})$, and triethylamine $(1 \mathrm{~mL})$ was added to the reaction mixture at a rate of $120 \mathrm{~mL} /$ hour. The mixture was then allowed to stir for 2 hours at RT. The material was then transferred to $20 \mathrm{~mL}$ vials and washed with DMF at $100^{\circ} \mathrm{C}$ five times for 24 hours each, followed by three washes with methanol at $45^{\circ} \mathrm{C}$ for 24 hours each. The material was then activated with flowing $\mathrm{N}_{2}$ at $150{ }^{\circ} \mathrm{C}$ for 48 hours.

\section{Synthesis of $\mathrm{Co}_{2}(\mathrm{bdc})_{2}(\mathrm{dabco})$}

The following synthesis has been modified from a previously published paper. ${ }^{6} \mathrm{Co}\left(\mathrm{NO}_{3}\right)_{2} \cdot 6 \mathrm{H}_{2} \mathrm{O}$ $(0.367 \mathrm{~g}, 1.26 \mathrm{mmol})$, terephthalic acid $(0.209 \mathrm{~g}, 1.26 \mathrm{mmol}), 1,4$-diazabycyclo[2.2.2]octane $(0.070 \mathrm{~g}, 0.624 \mathrm{mmol})$, and DMF $(15 \mathrm{~mL})$ were added to a $25 \mathrm{~mL}$ Teflon-lined steel autoclave and 
heated at $110^{\circ} \mathrm{C}$ for 24 hours. The purple solid was collected then washed three times with DMF and three times with $\mathrm{CHCl}_{3}$, then activated under dynamic vacuum at $120^{\circ} \mathrm{C}$ for 24 hours.

\section{Synthesis of Cr-MIL-100}

The following synthesis has been modified from a previously published paper. ${ }^{7} \mathrm{CrO}_{3}(0.25 \mathrm{~g}, 2.5$ $\mathrm{mmol})$, trimesic acid $(0.525 \mathrm{~g}, 2.5 \mathrm{mmol})$, hydrofluoric acid $(48 \%, 0.091 \mathrm{~mL})$, and $\mathrm{DI} \mathrm{H}_{2} \mathrm{O}(12 \mathrm{~mL})$ were combined in a $25 \mathrm{~mL}$ Teflon-lined steel autoclave, then heated at $220{ }^{\circ} \mathrm{C}$ for 48 hours. The solid was collected, washed with $\mathrm{H}_{2} \mathrm{O}$ then acetone, followed by activation with flowing $\mathrm{N}_{2}$ at 100 ${ }^{\circ} \mathrm{C}$ for 24 hours.

\section{Synthesis of Cr-MIL-101}

The following synthesis has been prepared according to literature methods. ${ }^{8}$

\section{Synthesis of DUT-4}

The following synthesis has been prepared according to literature methods. ${ }^{9}$

\section{Synthesis of Fe-MIL-100}

The following synthesis has been prepared according to literature methods. ${ }^{10}$

\section{Synthesis of HKUST-1 (Korman)}

The following synthesis has been modified from a previously published paper. ${ }^{11} \mathrm{Cu}\left(\mathrm{NO}_{3}\right)_{2} \cdot 2.5 \mathrm{H}_{2} \mathrm{O}$ $(3.87 \mathrm{~g}, 15.3 \mathrm{mmol})$, trimesic acid $(1.93 \mathrm{~g}, 9.18 \mathrm{mmol})$, and DMF $(100 \mathrm{~mL})$ were added to a 250 $\mathrm{mL}$ round-bottom flask then stirred at $75{ }^{\circ} \mathrm{C}$ for 48 hours. The solid was collected then soaked three times with DMF at $75^{\circ} \mathrm{C}$ for 12 hours then washed three more times with methanol at room temperature for 12 hours. The material was activated under vacuum at $180^{\circ} \mathrm{C}$ for 60 hours.

\section{Synthesis of HKUST-1 (Mason)}

The following synthesis has been prepared according to literature methods. ${ }^{3}$

\section{Synthesis of $\mathbf{M g}_{2}$ (dobdc)}

The following synthesis has been prepared according to literature methods. ${ }^{3}$

\section{Synthesis of $\mathrm{Mg}_{2}$ (dobdc)-RT}

The following synthesis has been modified from a previously published paper. ${ }^{4}$ In a $250 \mathrm{~mL}$ RBF $\mathrm{Mg}\left(\mathrm{NO}_{3}\right)_{2} \cdot 6 \mathrm{H}_{2} \mathrm{O}(1.399 \mathrm{~g}, 5.46 \mathrm{mmol})$ and $\mathrm{H}_{4}($ dobdc) $(336.8 \mathrm{mg}, 1.70 \mathrm{mmol})$ were dissolved in DMF $(135 \mathrm{~mL})$. Then using a syringe pump a solution containing ethanol $(9 \mathrm{~mL})$, water $(9 \mathrm{~mL})$, and triethylamine $(1 \mathrm{~mL})$ was added to the reaction mixture at a rate of $120 \mathrm{~mL} /$ hour. The mixture was then allowed to stir for 2 hours at RT. The material was then transferred to $20 \mathrm{~mL}$ vials and washed with DMF at $100^{\circ} \mathrm{C}$ five times for 24 hours each, followed by three washes with methanol at $45^{\circ} \mathrm{C}$ for 24 hours each. The material was then activated with flowing $\mathrm{N}_{2}$ at $150{ }^{\circ} \mathrm{C}$ for 48 hours.

\section{Synthesis of $\mathrm{Mg}_{2}$ (m-dobdc)-RT}

The following synthesis was based on a previously published paper. ${ }^{4}$ In a $250 \mathrm{~mL}$ RBF $\mathrm{Mg}\left(\mathrm{NO}_{3}\right)_{2} \cdot 6 \mathrm{H}_{2} \mathrm{O}(1.399 \mathrm{~g}, 5.46 \mathrm{mmol})$ and $\mathrm{H}_{4}(m$-dobdc) $(336.8 \mathrm{mg}, 1.70 \mathrm{mmol})$ were dissolved in DMF $(135 \mathrm{~mL})$. Then using a syringe pump a solution containing ethanol $(9 \mathrm{~mL})$, water $(9 \mathrm{~mL})$, and triethylamine $(1 \mathrm{~mL})$ was added to the reaction mixture at a rate of $120 \mathrm{~mL} /$ hour. The mixture was then allowed to stir for 2 hours at RT. The material was then transferred to $20 \mathrm{~mL}$ vials and washed with DMF at $100^{\circ} \mathrm{C}$ five times for 24 hours each, followed by three washes with methanol at $45^{\circ} \mathrm{C}$ for 24 hours each. The material was then activated with flowing $\mathrm{N}_{2}$ at $150{ }^{\circ} \mathrm{C}$ for 48 hours.

\section{Synthesis of MIL-125- $\mathrm{NH}_{2}$}


The following synthesis has been prepared according to literature methods. ${ }^{12}$

\section{Synthesis of MIL-88A}

The following synthesis has been prepared according to literature methods. ${ }^{13}$

\section{Synthesis of MIL-88C}

The following synthesis has been prepared according to literature methods. ${ }^{13}$

\section{Synthesis of MOF-801}

The following synthesis has been prepared according to literature methods. ${ }^{14}$

\section{Synthesis of MOF-808}

The following synthesis has been prepared according to literature methods. ${ }^{14}$

\section{Synthesis of $\mathrm{Ni}_{2}$ (dobdc)}

The following synthesis has been modified from a previously published paper. ${ }^{3} \mathrm{Ni}\left(\mathrm{NO}_{3}\right)_{2} \cdot 6 \mathrm{H}_{2} \mathrm{O}$ (5.23 g, $18 \mathrm{mmol}$ ) and $\mathrm{H}_{4}$ (dobdc) $(1.42 \mathrm{~g}, 7.2 \mathrm{mmol}$ ) were combined with anhydrous DMF (350 $\mathrm{mL}$ ) and anhydrous methanol $(42 \mathrm{~mL})$ in a $500 \mathrm{~mL}$ Schlenk flask. The solution stirred under $\mathrm{N}_{2}$ pressure at $120^{\circ} \mathrm{C}$ for 18 hours. The solution was allowed to cool while the yellow powder settled to the bottom of the flask. The solution was removed via cannula and replaced with fresh DMF, then soaked at $100{ }^{\circ} \mathrm{C}$ for 6 hours. The solution was removed and replaced twice more with fresh $\mathrm{DMF}$, then repeated three more times with fresh methanol at $60^{\circ} \mathrm{C}$ for 6 hours each. The material was collected then activated with flowing $\mathrm{N}_{2}$ at $180{ }^{\circ} \mathrm{C}$ for 48 hours followed by dynamic vacuum at $180{ }^{\circ} \mathrm{C}$ for 24 hours.

\section{Synthesis of $\mathrm{Ni}_{2}$ (dobdc)-RT}

The following synthesis has been modified from a previously published paper. ${ }^{4}$ In a $250 \mathrm{~mL}$ RBF $\mathrm{Ni}\left(\mathrm{NO}_{3}\right)_{2} \cdot 6 \mathrm{H}_{2} \mathrm{O}(1.587 \mathrm{~g}, 5.46 \mathrm{mmol})$ and $\mathrm{H}_{4}$ (dobdc) $(336.8 \mathrm{mg}, 1.70 \mathrm{mmol})$ were dissolved in DMF (135 $\mathrm{mL})$. Then using a syringe pump a solution containing ethanol $(9 \mathrm{~mL})$, water $(9 \mathrm{~mL})$, and triethylamine $(1 \mathrm{~mL})$ was added to the reaction mixture at a rate of $120 \mathrm{~mL} /$ hour. The mixture was then allowed to stir for 2 hours at RT. The material was then transferred to $20 \mathrm{~mL}$ vials and washed with DMF at $100^{\circ} \mathrm{C}$ five times for 24 hours each, followed by three washes with methanol at $45^{\circ} \mathrm{C}$ for 24 hours each. The material was then activated with flowing $\mathrm{N}_{2}$ at $150{ }^{\circ} \mathrm{C}$ for 48 hours.

\section{Synthesis of $\mathrm{Ni}(\mathrm{m}$-bdc)}

The following synthesis has been prepared according to literature methods. ${ }^{15}$

\section{Synthesis of $\mathrm{Ni}_{2}$ (m-dobdc)}

The following synthesis has been modified from a previously published paper. ${ }^{5}$ Anhydrous methanol $(70 \mathrm{~mL})$ and anhydrous DMF $(130 \mathrm{~mL})$ were added to a $500 \mathrm{~mL}$ three-neck roundbottom flask equipped with a reflux condenser and sparged with $\mathrm{N}_{2}$ for one hour. $\mathrm{NiCl}_{2}(1.05 \mathrm{~g}$, $8.02 \mathrm{mmol})$ and $\mathrm{H}_{4}(m$-dobdc $)(0.640 \mathrm{~g}, 3.23 \mathrm{mmol})$ were added under $\mathrm{N}_{2}$ pressure and stirred at $120^{\circ} \mathrm{C}$ for 18 hours. The solid was isolated and washed with DMF at $70{ }^{\circ} \mathrm{C}$ for 24 hours, followed by four more washes with methanol at $70{ }^{\circ} \mathrm{C}$. The material was then activated under dynamic vacuum at $180^{\circ} \mathrm{C}$ for 24 hours.

\section{Synthesis of $\mathrm{Ni}_{2}$ (m-dobdc)-RT}

The following synthesis was based on a previously published paper. ${ }^{4}$ In a $250 \mathrm{~mL}$ RBF $\mathrm{Ni}\left(\mathrm{NO}_{3}\right)_{2} \cdot 6 \mathrm{H}_{2} \mathrm{O}(1.587 \mathrm{~g}, 5.46 \mathrm{mmol})$ and $\mathrm{H}_{4}\left(m_{\text {-dobdc }}\right)(336.8 \mathrm{mg}, 1.70 \mathrm{mmol})$ were dissolved in DMF (135 $\mathrm{mL})$. Then using a syringe pump a solution containing ethanol $(9 \mathrm{~mL})$, water $(9 \mathrm{~mL})$, and triethylamine $(1 \mathrm{~mL})$ was added to the reaction mixture at a rate of $120 \mathrm{~mL} /$ hour. The mixture 
was then allowed to stir for 2 hours at RT. The material was then transferred to $20 \mathrm{~mL}$ vials and washed with DMF at $100^{\circ} \mathrm{C}$ five times for 24 hours each, followed by three washes with methanol at $45^{\circ} \mathrm{C}$ for 24 hours each. The material was then activated with flowing $\mathrm{N}_{2}$ at $150{ }^{\circ} \mathrm{C}$ for 48 hours.

\section{Synthesis of NOTT-101}

The following synthesis has been prepared according to literature methods. ${ }^{16}$

\section{Synthesis of PAF-1}

The following synthesis has been prepared according to literature methods, with modifications to washing and activation. ${ }^{17}$ The sample was washed via soxhlet with THF at $75^{\circ} \mathrm{C}$ for 48 hours. The sample was then dried with flowing $\mathrm{N}_{2}$ at room temperature for 24 hours, then $100{ }^{\circ} \mathrm{C}$ for 48 hours.

\section{Synthesis of Ti-MIL-100}

The following synthesis has been prepared according to literature methods. ${ }^{18}$

\section{Synthesis of Ti-MIL-101}

The following synthesis has been prepared according to literature methods. ${ }^{18}$

\section{Synthesis of UiO-66 Water Modulated Particles}

The following synthesis has been prepared according to literature methods. ${ }^{19}$ The six samples used were synthesized using Ligand:Metal ratios of $1: 1,1.5: 1$, and $2: 1$ and either $50 \mu \mathrm{L}(7.2$ equivalents) or $400 \mu \mathrm{L}$ (57.5 equivalents) of water.

\section{Synthesis of UiO-66 High SA}

The following synthesis has been modified from a previously published paper. ${ }^{20}$ In a 1 liter glass media bottle $\mathrm{ZrCl}_{4}(4.00 \mathrm{~g}, 17.2 \mathrm{mmol})$, concentrated $\mathrm{HCl}(32 \mathrm{~mL})$, and DMF $(160 \mathrm{~mL})$ were sonicated for 20 minutes until fully dissolved. Terephthalic acid (3.94 g, $23.7 \mathrm{mmol})$ and DMF (320 $\mathrm{mL}$ ) were added to the mixture and sonicated for an additional 20 minutes. After sonication the 1liter glass media bottle was heated at $80{ }^{\circ} \mathrm{C}$ overnight. The resulting product was isolated via centrifugation and washed five times with DMF and five times with methanol. Material was then dried with flowing $\mathrm{N}_{2}$ at room temperature followed by vacuum activation at $100{ }^{\circ} \mathrm{C}$ for two days.

\section{Synthesis of UiO-66-(COOH) 2}

The following synthesis has been prepared according to literature methods. ${ }^{21}$

\section{Synthesis of UiO-66- $\mathrm{NH}_{2}$}

The following synthesis has been modified from a previously published paper. ${ }^{20}$ In a 1 liter glass media bottle $\mathrm{ZrCl}_{4}(4.00 \mathrm{~g}, 17.2 \mathrm{mmol})$, concentrated $\mathrm{HCl}(32 \mathrm{~mL})$, and DMF $(160 \mathrm{~mL})$ were sonicated for 20 minutes until fully dissolved. 2-amino Terephthalic acid (3.94 g, $23.7 \mathrm{mmol})$ and DMF $(320 \mathrm{~mL})$ were added to the mixture and sonicated for an additional 20 minutes. After sonication the 1 -liter glass media bottle was heated at $80^{\circ} \mathrm{C}$ overnight. The resulting product was isolated via centrifugation and washed five times with DMF and five times with methanol. Material was then dried with flowing $\mathrm{N}_{2}$ at room temperature followed by vacuum activation at $100{ }^{\circ} \mathrm{C}$ for two days.

\section{Synthesis of UiO-66-Acetyl}

In a $1 \mathrm{~L}$ glass media bottle 2-acetyl terephthalic acid $(3.4 \mathrm{~g}, 14.3 \mathrm{mmol})$ was combined with $\mathrm{ZrCl}_{4}$ $(2.0 \mathrm{~g}, 8.6 \mathrm{mmol})$ in DMF $(240 \mathrm{~mL})$ and concentrated $\mathrm{HCl}(16 \mathrm{~mL})$. The solution was heated to $120^{\circ} \mathrm{C}$ overnight, which resulted in the formation of white powder. The solvent was replaced with 
fresh DMF three times over the course of two days. Similarly, the solvent was exchanged with fresh methanol three times. The product was activated under flowing $\mathrm{N}_{2}$ at $120{ }^{\circ} \mathrm{C}$ for 24 hours.

\section{Synthesis of UiO-66-Butyrl}

In a $500 \mathrm{~mL}$ glass media bottle 2-butyrl terephthalic acid $(3.4 \mathrm{~g}, 13.5 \mathrm{mmol})$ was combined with $\mathrm{ZrCl}_{4}(2.0 \mathrm{~g}, 8.6 \mathrm{mmol})$ in DMF $(240 \mathrm{~mL})$ and concentrated $\mathrm{HCl}(16 \mathrm{~mL})$. The solution was heated to $120{ }^{\circ} \mathrm{C}$ overnight, which resulted in the formation of white powder. The solvent was replaced with fresh DMF three times over the course of two days. Similarly, the solvent was exchanged with fresh methanol three times. The product was activated under flowing $\mathrm{N}_{2}$ at $120{ }^{\circ} \mathrm{C}$ for 24 hours.

\section{Synthesis of UiO-67}

The following synthesis has been modified from a previously published paper. ${ }^{20}$ In a 1-liter glass media bottle $\mathrm{ZrCl}_{4}(2.14 \mathrm{~g}, 9.20 \mathrm{mmol})$, concentrated $\mathrm{HCl}(16 \mathrm{~mL})$, and DMF $(160 \mathrm{~mL})$ were sonicated for 20 minutes until fully dissolved. Biphenyl-4,4'-dicarboxylic acid $(2.80 \mathrm{~g}, 11.9 \mathrm{mmol})$ and DMF (320 mL) were added to the mixture and sonicated for an additional 20 minutes. After sonication the 1 liter glass media bottle was heated at $80^{\circ} \mathrm{C}$ overnight. The resulting product was isolated via centrifugation and washed five times with DMF and five times with methanol. Material was then dried with flowing $\mathrm{N}_{2}$ at room temperature followed by vacuum activation at $125{ }^{\circ} \mathrm{C}$ for two days.

\section{Synthesis of V-MIL-100}

The following synthesis has been prepared according to literature methods. ${ }^{22}$

\section{Synthesis of $\mathrm{Zn}_{2}$ (dobdc)-RT}

The following synthesis has been modified from a previously published paper. ${ }^{4}$ In a $250 \mathrm{~mL} \mathrm{RBF}$ $\mathrm{Zn}\left(\mathrm{NO}_{3}\right)_{2} \cdot 6 \mathrm{H}_{2} \mathrm{O}(1.624 \mathrm{~g}, 5.46 \mathrm{mmol})$ and $\mathrm{H}_{4}($ dobdc) $(336.8 \mathrm{mg}, 1.70 \mathrm{mmol})$ were dissolved in DMF $(135 \mathrm{~mL})$. Then using a syringe pump a solution containing ethanol $(9 \mathrm{~mL})$, water $(9 \mathrm{~mL})$, and triethylamine $(1 \mathrm{~mL})$ was added to the reaction mixture at a rate of $120 \mathrm{~mL} /$ hour. The mixture was then allowed to stir for 2 hours at RT. The material was then transferred to $20 \mathrm{~mL}$ vials and washed with DMF at $100^{\circ} \mathrm{C}$ five times for 24 hours each, followed by three washes with methanol at $45^{\circ} \mathrm{C}$ for 24 hours each. The material was then activated with flowing $\mathrm{N}_{2}$ at $150{ }^{\circ} \mathrm{C}$ for 48 hours.

\section{Calculation of $\mathrm{Mg}_{2}(\mathrm{~m}$-dobdc) Crystallographic Density.}

The crystallographic density of $\mathrm{Mg}_{2}\left(m\right.$-dobdc) was calculated using the cif for $\mathrm{Co}_{2}(m$-dobdc). First a few assumptions were made, based off the similarities between the unit cell dimensions for $\mathrm{Co}_{2}$ (dobdc) and $\mathrm{Mg}_{2}$ (dobdc) it was assumed that the unit cell dimensions for $\mathrm{Mg}_{2}$ ( $m$-dobdc) would be similar to $\mathrm{Co}_{2}\left(m\right.$-dobdc). The crystallographic density of $\mathrm{Mg}_{2}(\mathrm{dobdc})$ is $0.909 \mathrm{~g} / \mathrm{cm}^{3}$, and when utilizing the CIF for $\mathrm{Co}_{2}$ (dobdc) and replacing the Co atoms with $\mathrm{Mg}$ atoms the calculated density is $0.910 \mathrm{~g} / \mathrm{cm}^{3}$, this calculated density is within $0.1 \%$ of the published density for $\mathrm{Mg}_{2}$ (dobdc). With these two assumptions in mind, replacing the Co atoms in the $\mathrm{Co}_{2}(\mathrm{~m}$ dobdc) structure with $\mathrm{Mg}$ atoms yields a calculated crystallographic density of $0.924 \mathrm{~g} / \mathrm{cm}^{3}$. This calculated density represents the density of the $\mathrm{Mg}_{2}(m$-dobdc)-RT particles in this study. 


\section{Gas Adsorption Isotherms}

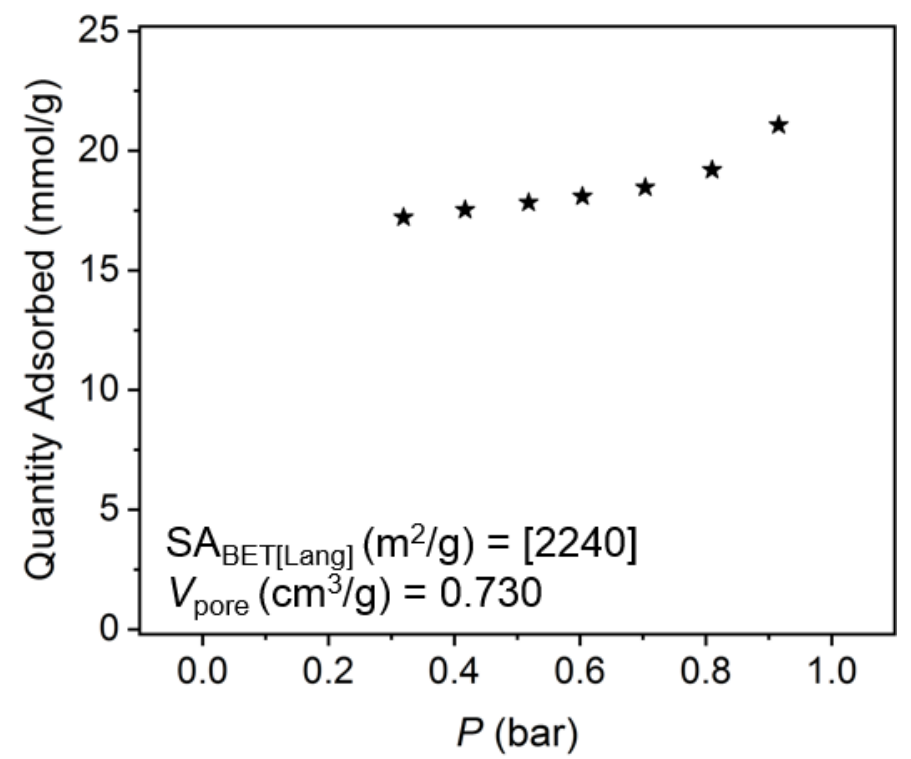

Figure S3. Adsorption of $\mathrm{N}_{2}$ in Al-MIL-101- $\mathrm{NH}_{2}$ at $77 \mathrm{~K}$.

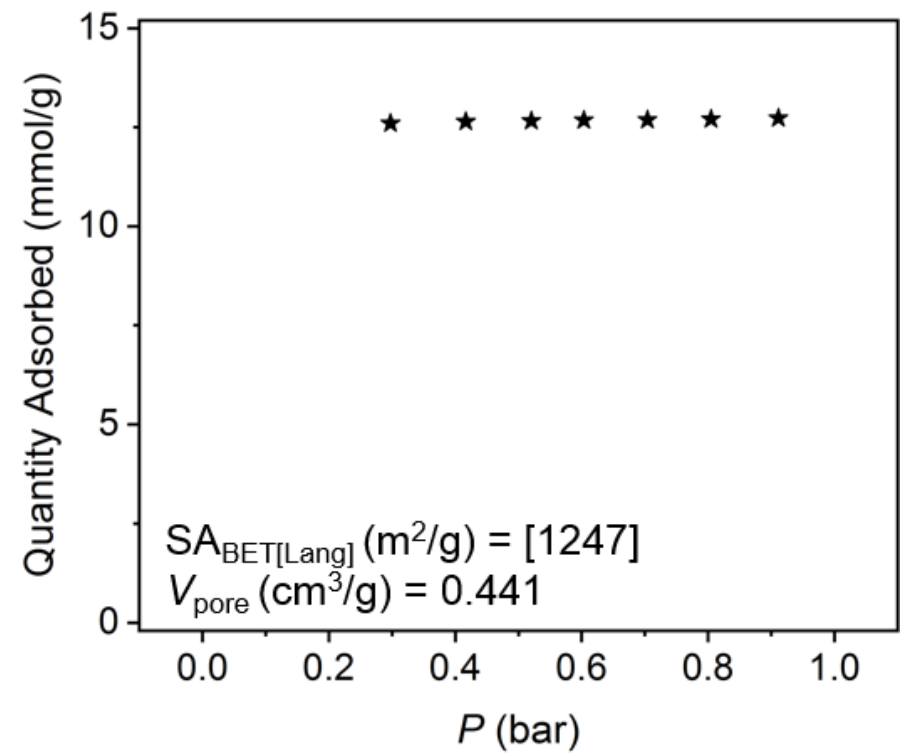

Figure S4. Adsorption of $\mathrm{N}_{2}$ in Al-MIL-53 at $77 \mathrm{~K}$. 


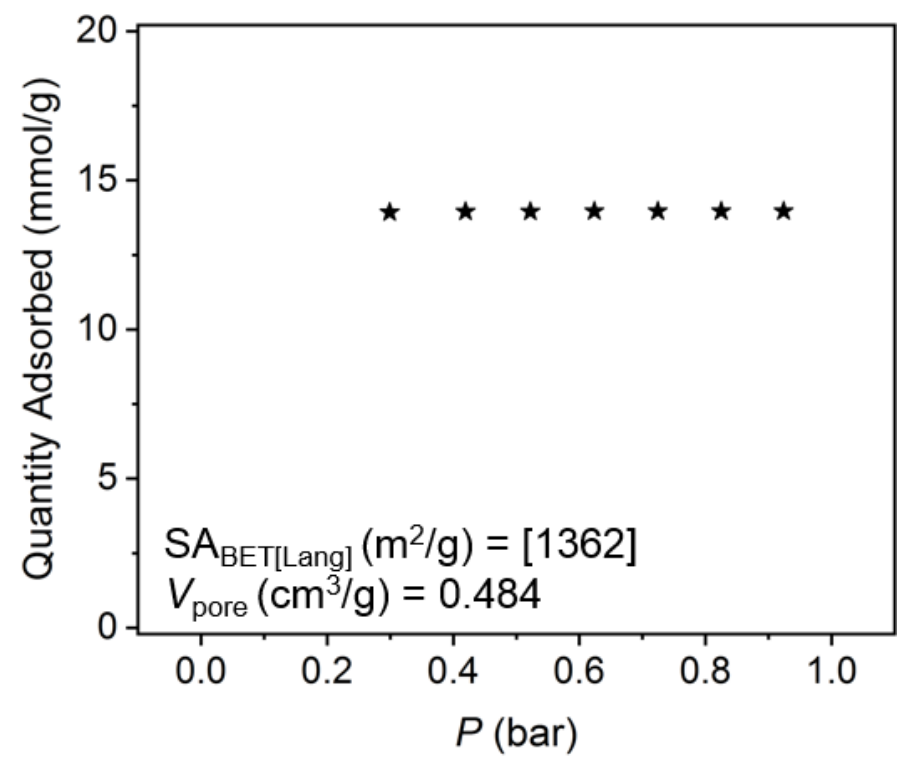

Figure S5. Adsorption of $\mathrm{N}_{2}$ in $\mathrm{Co}_{2}$ (dobdc) at $77 \mathrm{~K}$.

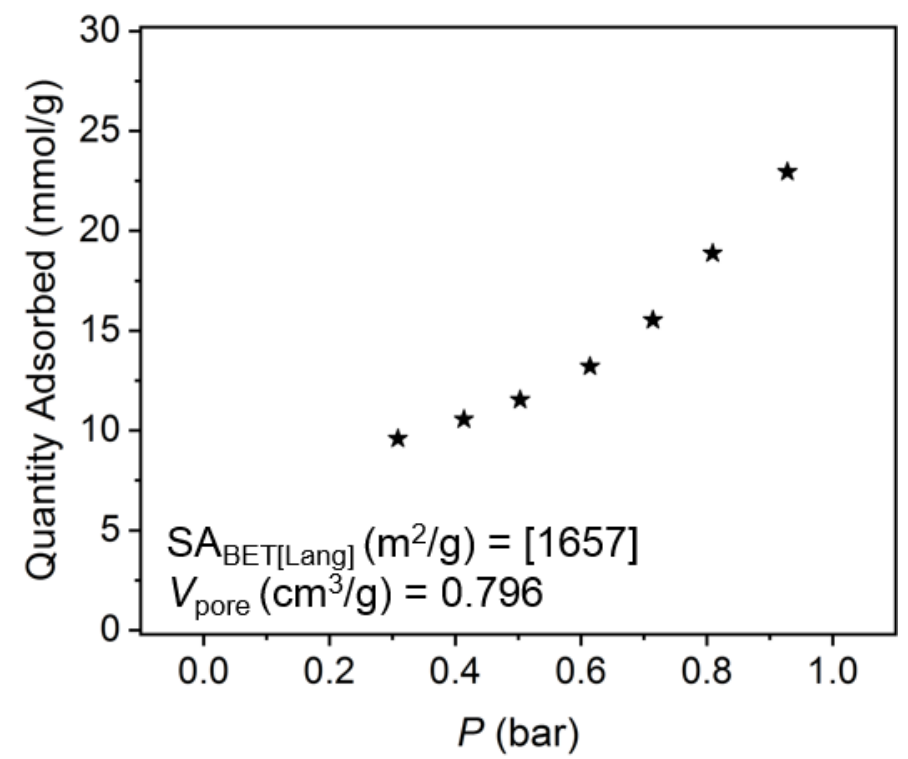

Figure S6. Adsorption of $\mathrm{N}_{2}$ in $\mathrm{Co}_{2}$ (dobdc) at $77 \mathrm{~K}$. 


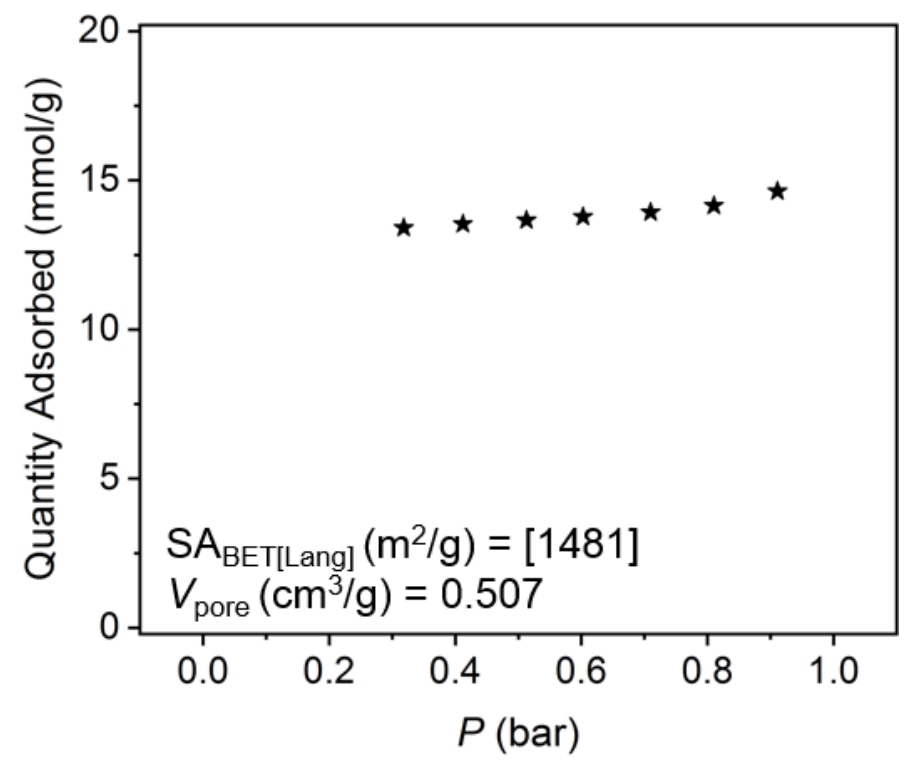

Figure S7. Adsorption of $\mathrm{N}_{2}$ in $\mathrm{Co}_{2}(m-d o b d c)$ at $77 \mathrm{~K}$.

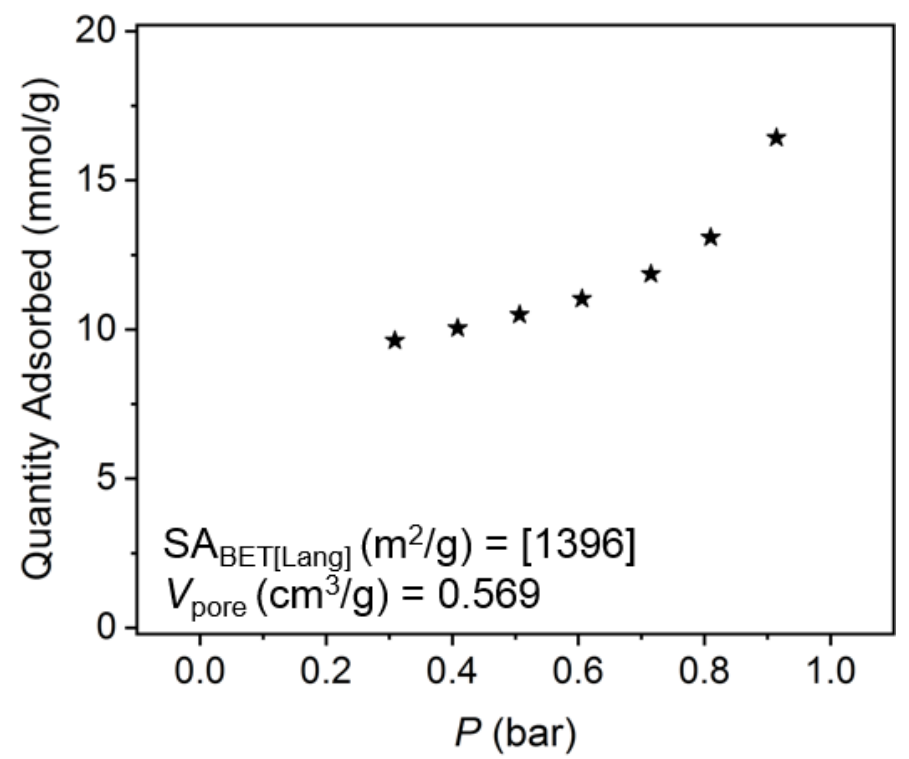

Figure S8. Adsorption of $\mathrm{N}_{2}$ in $\mathrm{Co}_{2}$ (m-dobdc)-RT at $77 \mathrm{~K}$. 


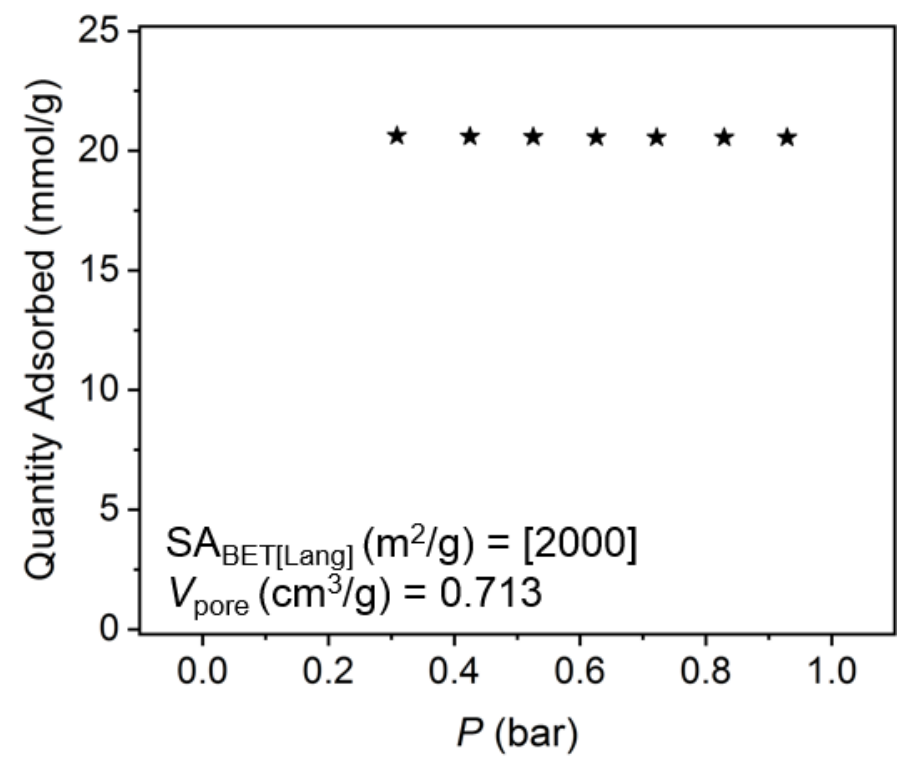

Figure S9. Adsorption of $\mathrm{N}_{2}$ in $\mathrm{Co}_{2}(\mathrm{bdc})_{2}($ dabco $)$ at $77 \mathrm{~K}$.

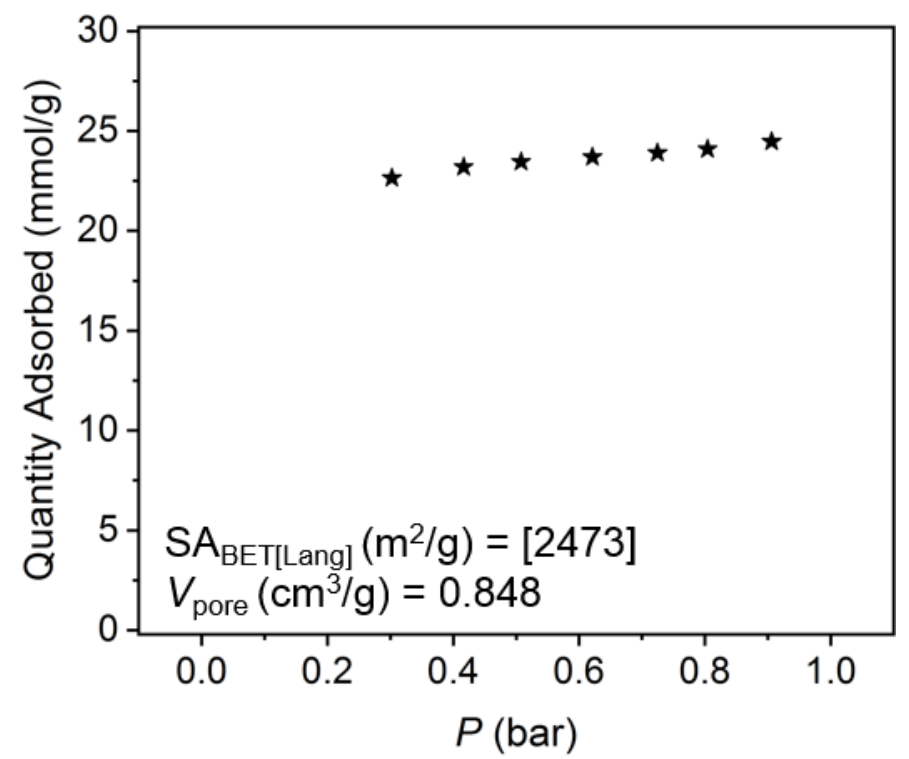

Figure S10. Adsorption of $\mathrm{N}_{2}$ in Cr-MIL-100 at $77 \mathrm{~K}$. 


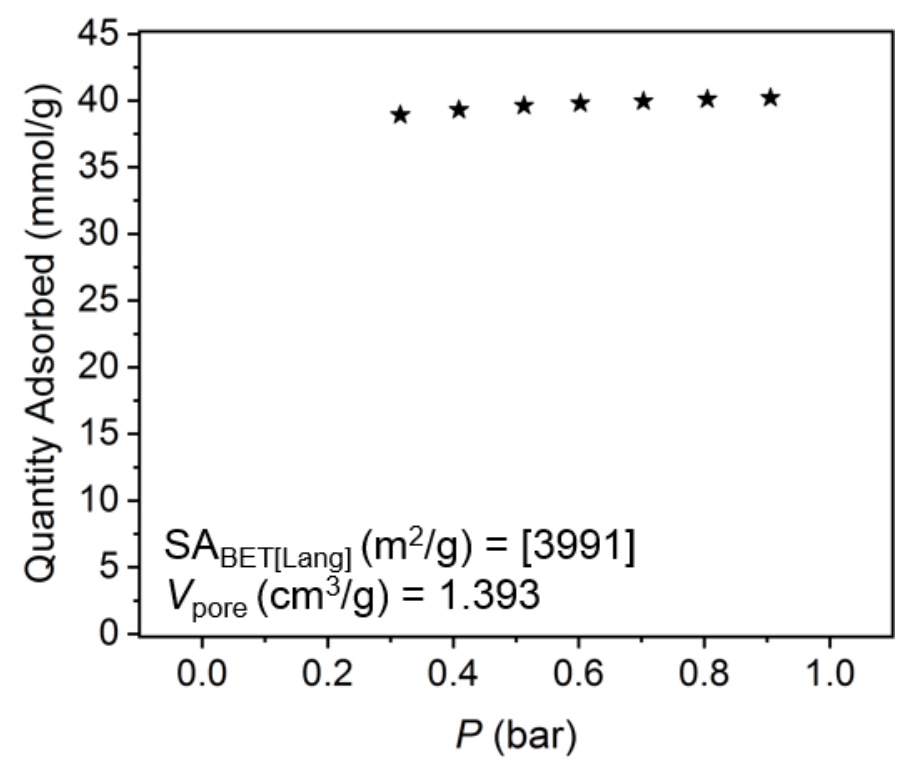

Figure S11. Adsorption of $\mathrm{N}_{2}$ in Cr-MIL-101 at $77 \mathrm{~K}$.

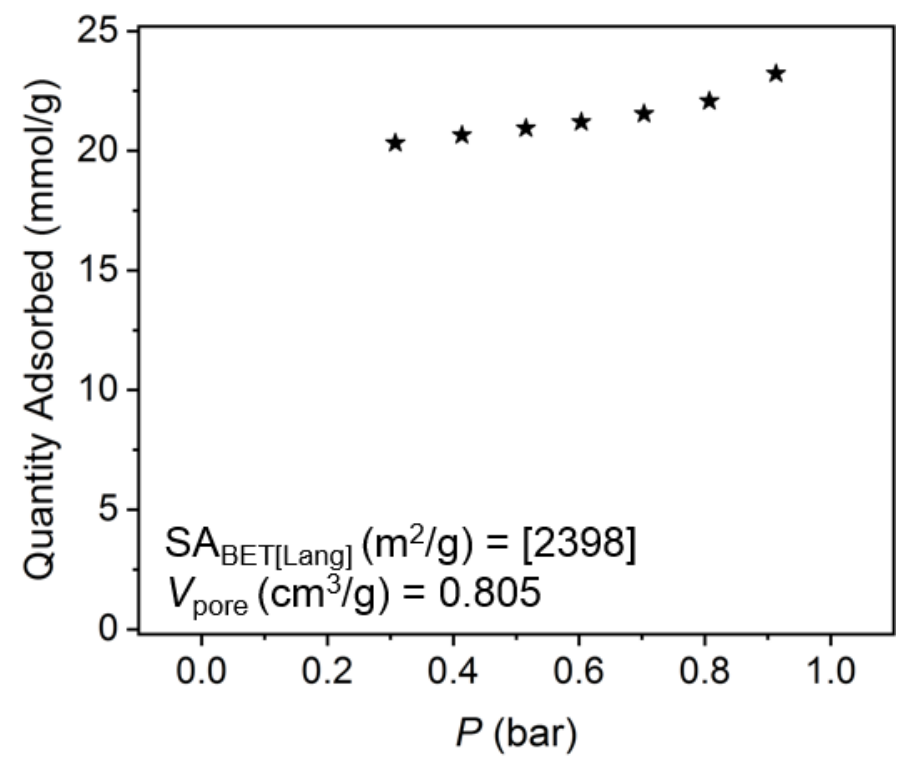

Figure S12. Adsorption of $\mathrm{N}_{2}$ in DUT-4 \#1 at $77 \mathrm{~K}$. 


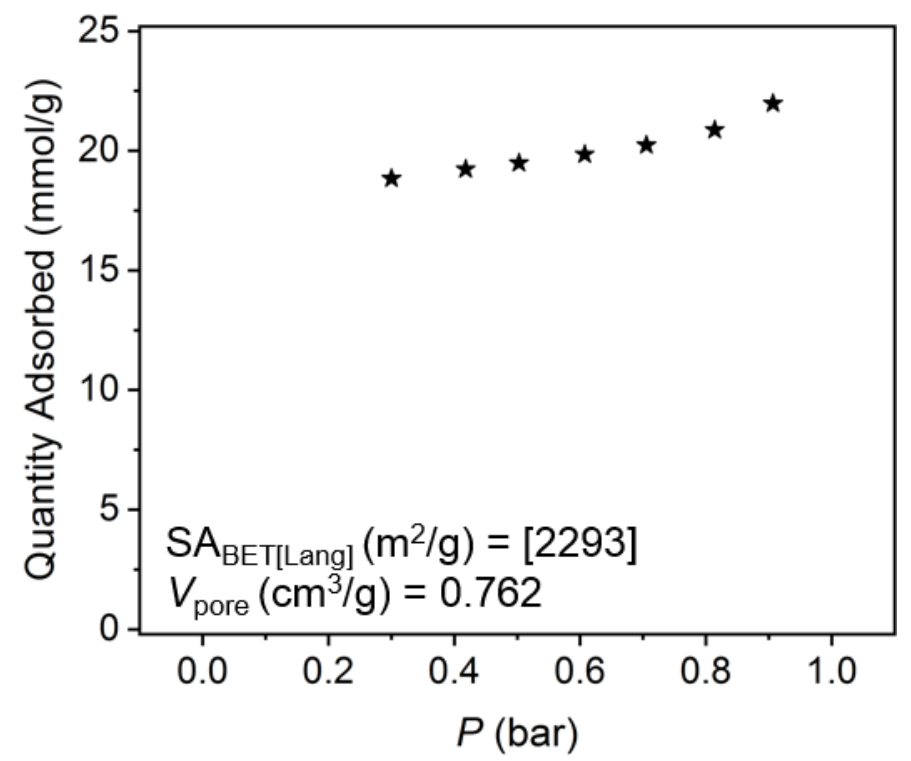

Figure S13. Adsorption of $\mathrm{N}_{2}$ in DUT-4 \#2 at $77 \mathrm{~K}$.

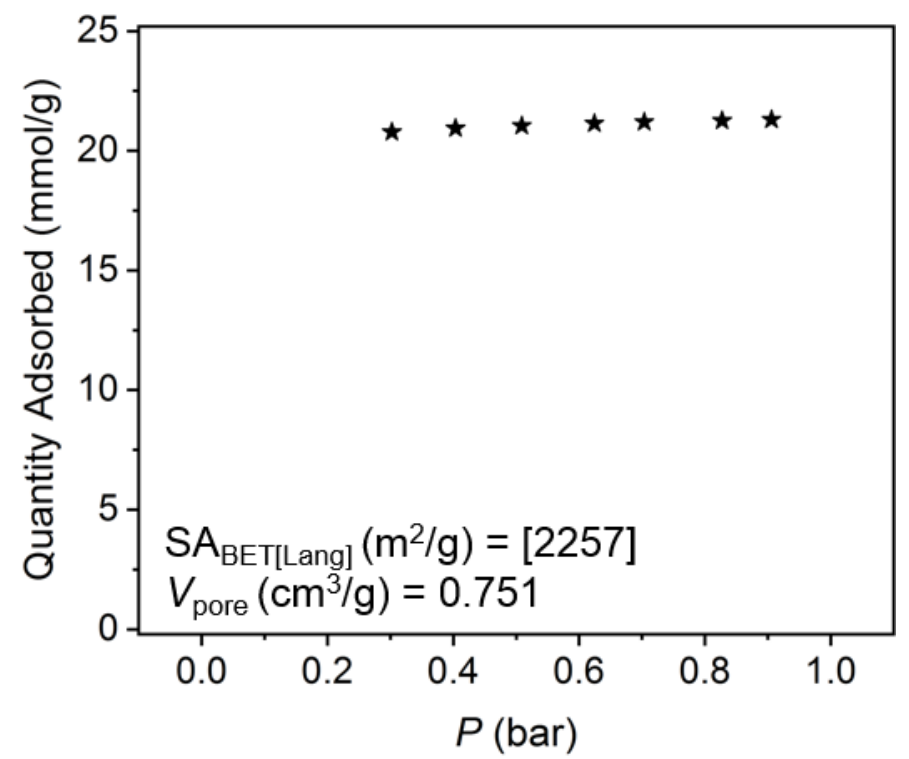

Figure S14. Adsorption of $\mathrm{N}_{2}$ in DUT-4 \#3 at $77 \mathrm{~K}$. 


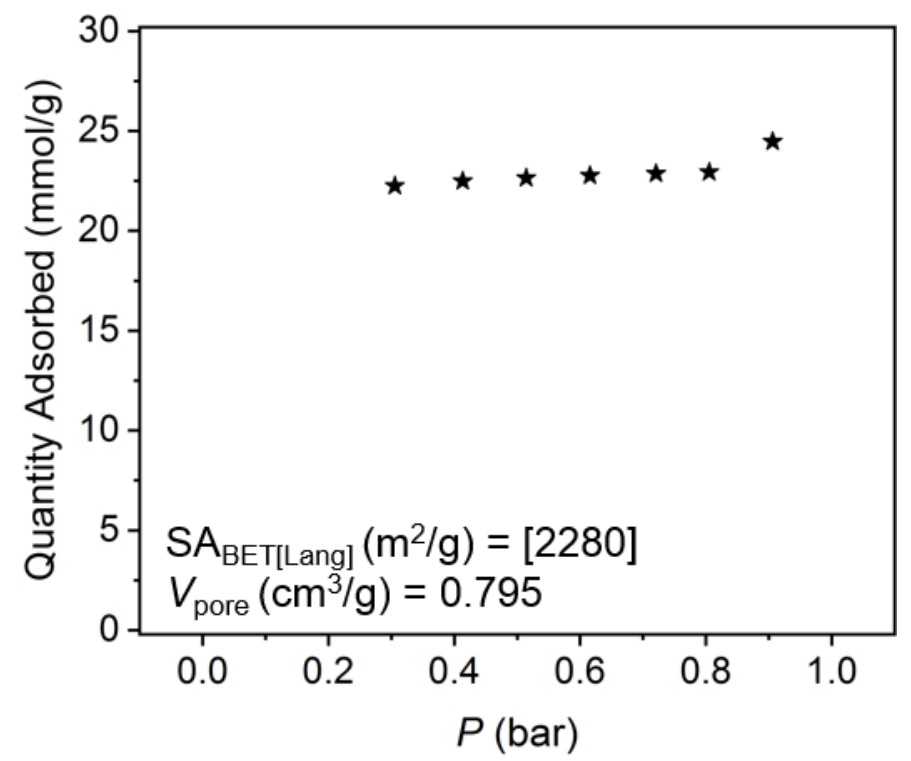

Figure S15. Adsorption of $\mathrm{N}_{2}$ in Fe-MIL-100 at $77 \mathrm{~K}$.

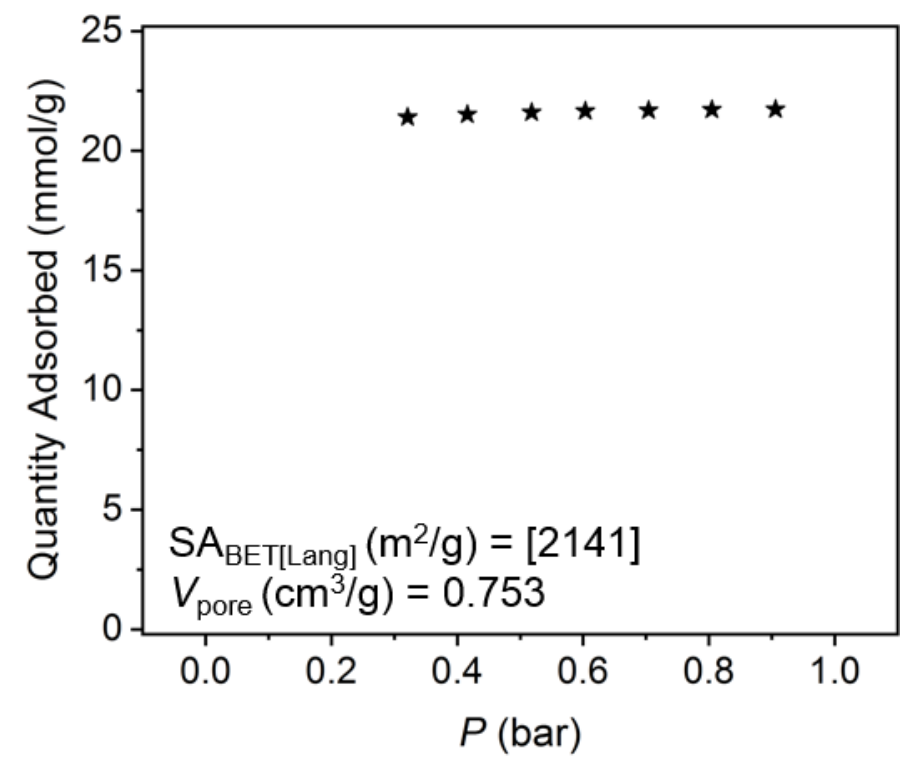

Figure S16. Adsorption of $\mathrm{N}_{2}$ in HKUST-1 (Korman) at $77 \mathrm{~K}$. 




Figure S17. Adsorption of $\mathrm{N}_{2}$ in HKUST-1 (Mason) at $77 \mathrm{~K}$.

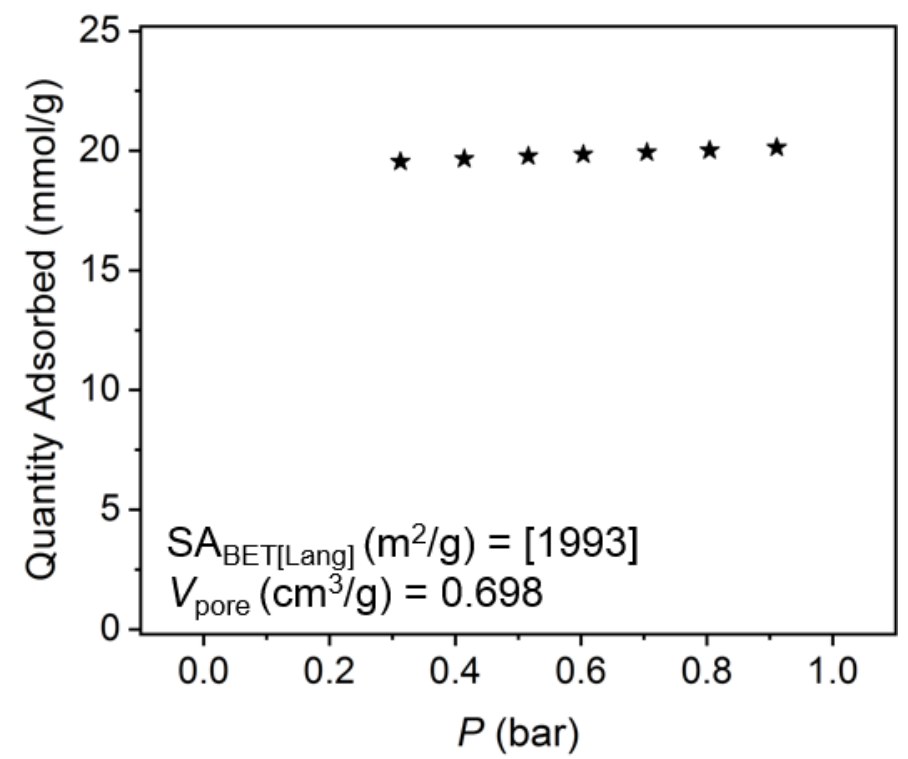

Figure S18. Adsorption of $\mathrm{N}_{2}$ in $\mathrm{Mg}_{2}$ (dobdc) at $77 \mathrm{~K}$. 


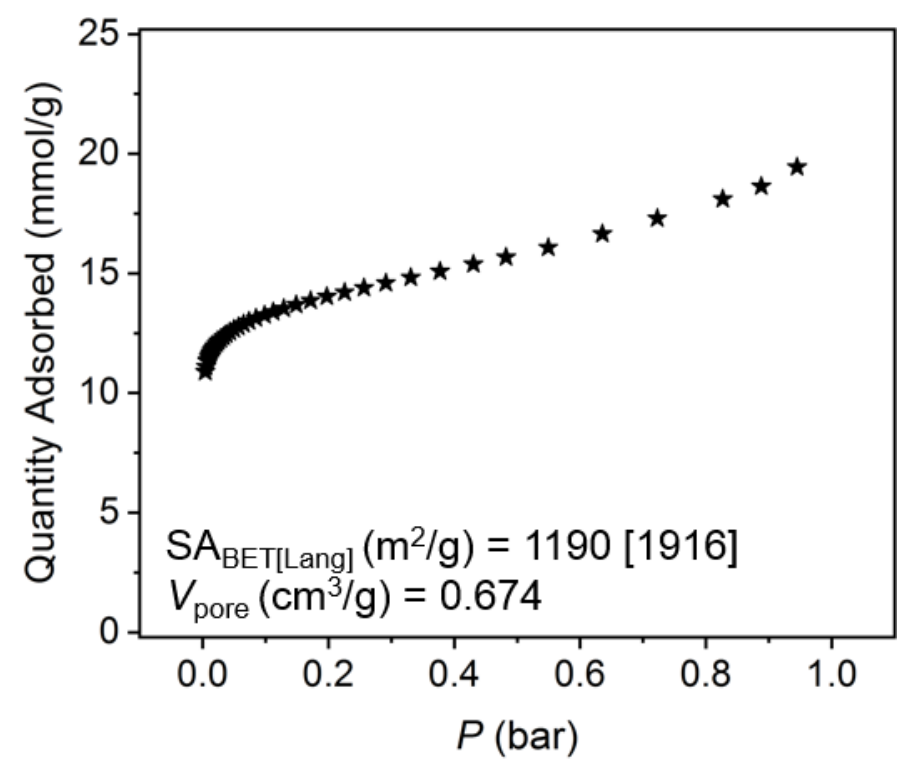

Figure S19. Adsorption of $\mathrm{N}_{2}$ in $\mathrm{Mg}_{2}$ (dobdc)-RT at $77 \mathrm{~K}$.

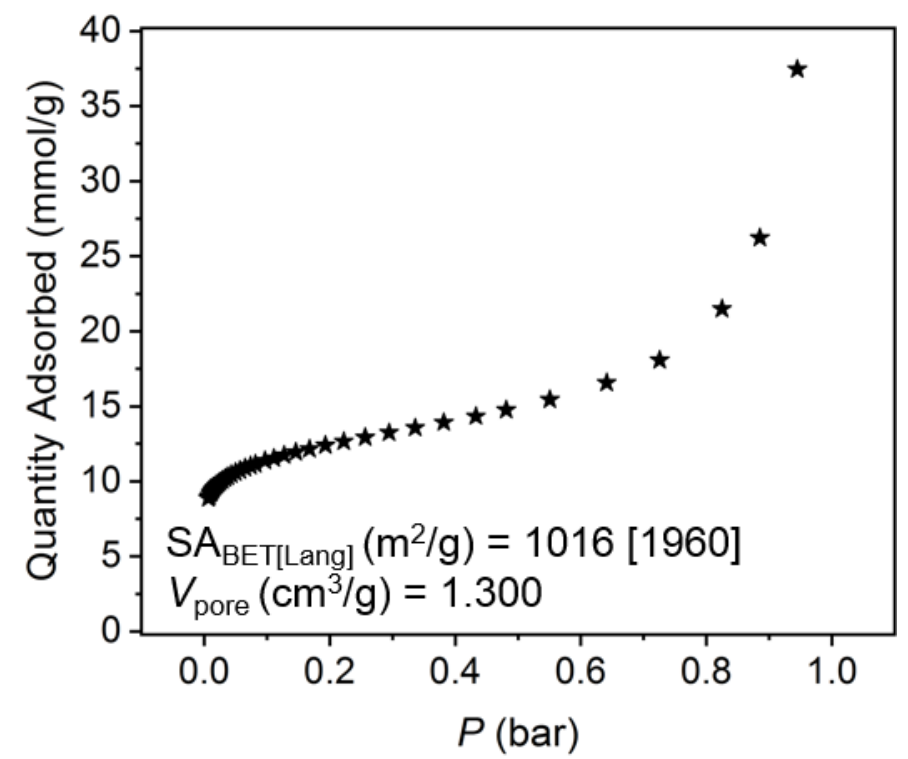

Figure S20. Adsorption of $\mathrm{N}_{2}$ in $\mathrm{Mg}_{2}(m$-dobdc)-RT at $77 \mathrm{~K}$. 


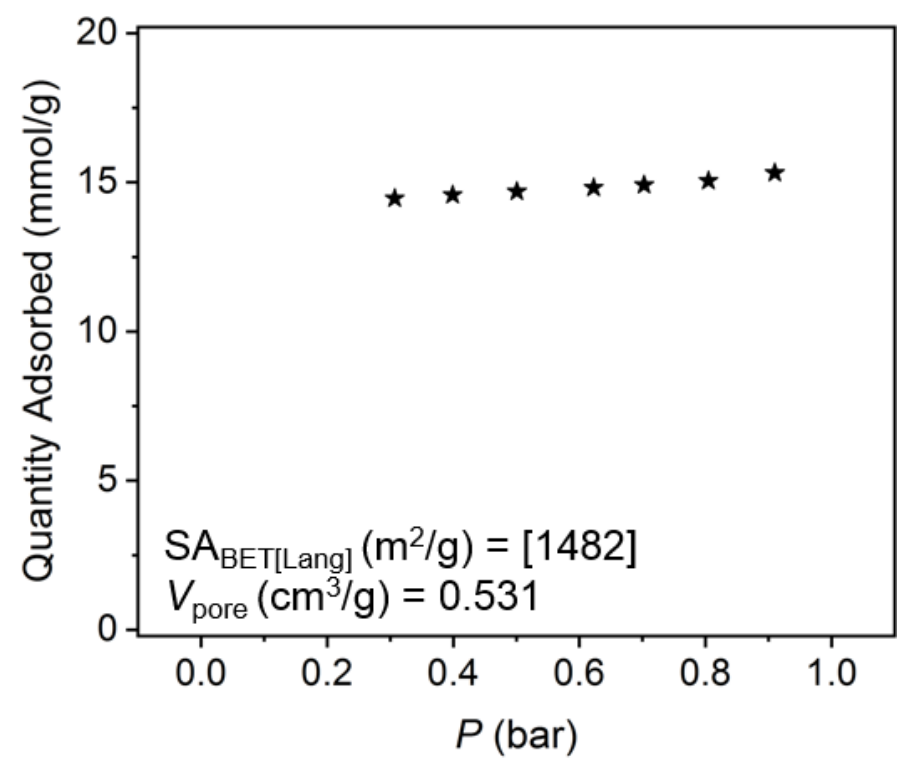

Figure S21. Adsorption of $\mathrm{N}_{2}$ in MIL-125- $\mathrm{NH}_{2}$ at $77 \mathrm{~K}$.

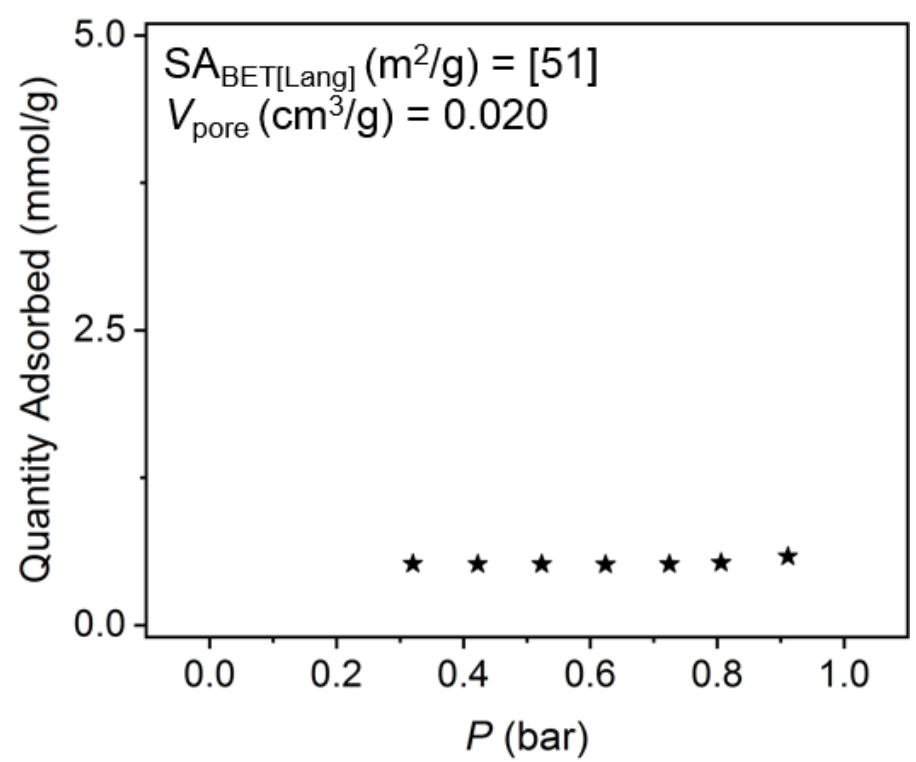

Figure S22. Adsorption of $\mathrm{N}_{2}$ in MIL-88A at $77 \mathrm{~K}$. 


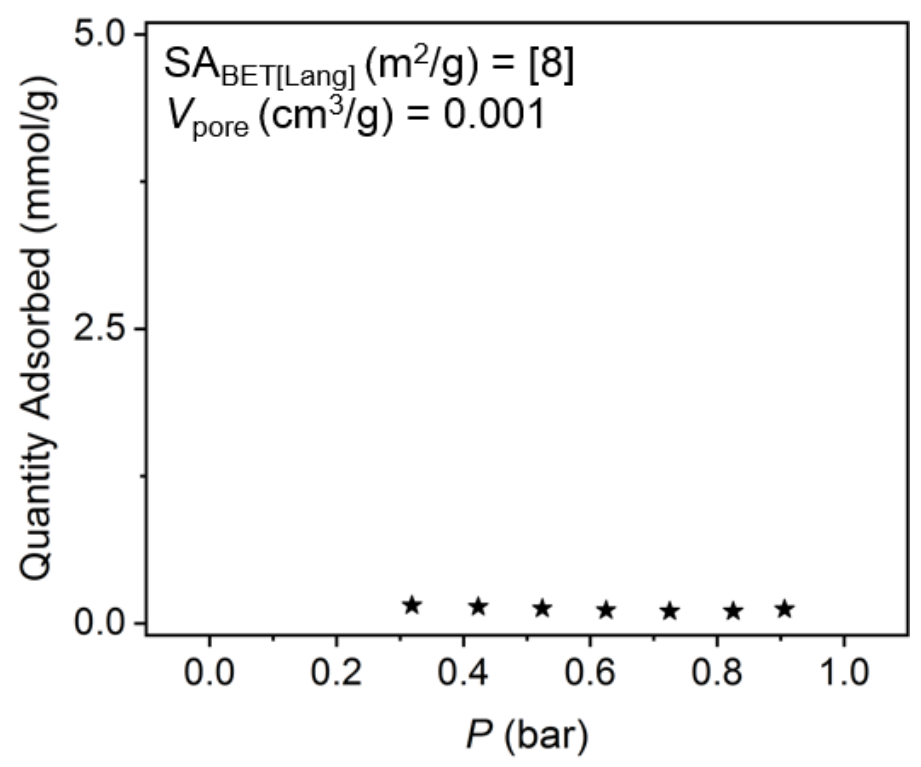

Figure S23. Adsorption of $\mathrm{N}_{2}$ in MIL-88C at $77 \mathrm{~K}$.

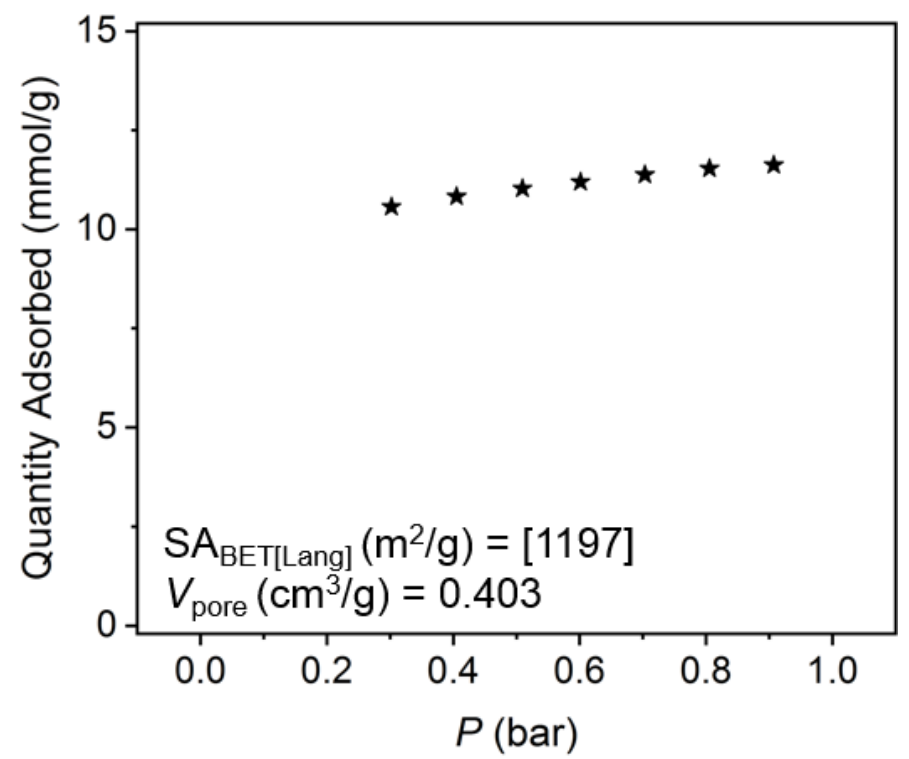

Figure S24. Adsorption of $\mathrm{N}_{2}$ in MOF-801 at $77 \mathrm{~K}$. 


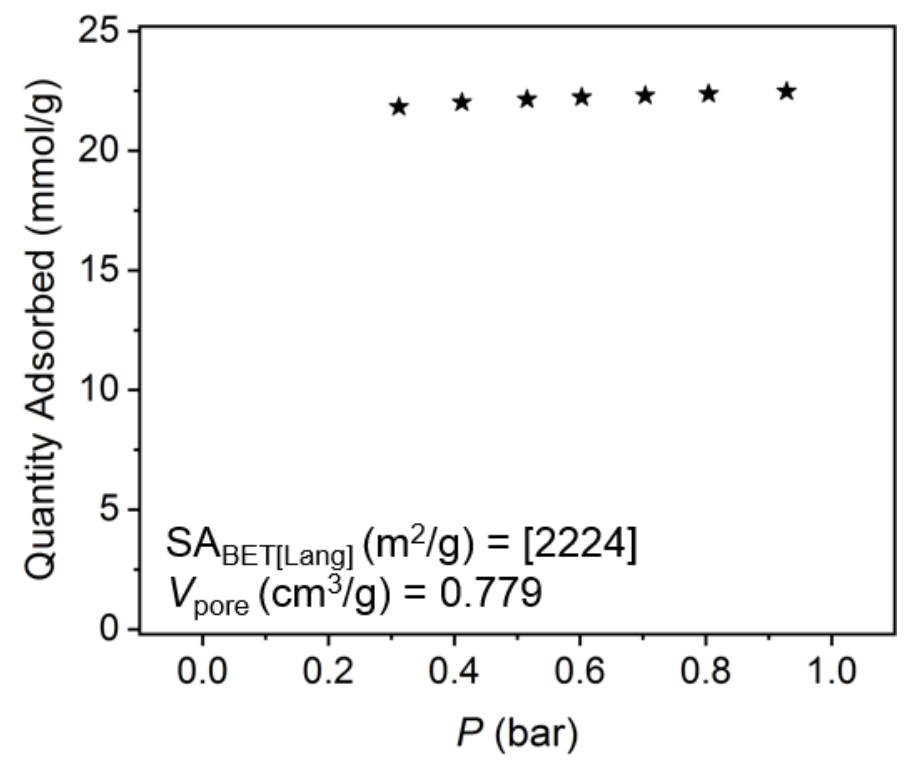

Figure S25. Adsorption of $\mathrm{N}_{2}$ in MOF-808 at $77 \mathrm{~K}$.

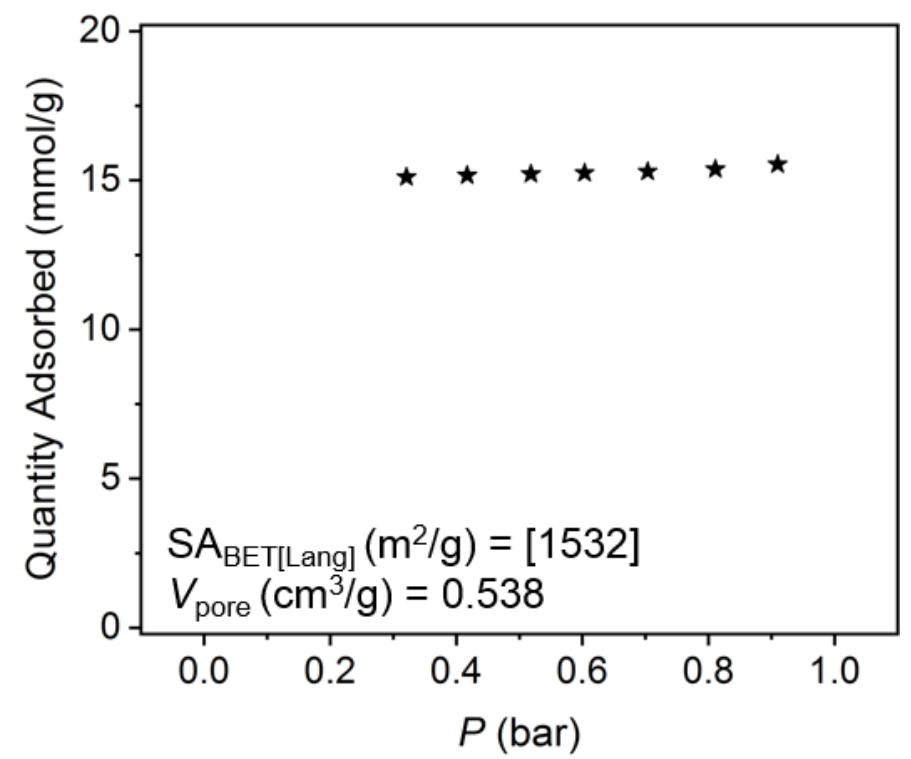

Figure S26. Adsorption of $\mathrm{N}_{2}$ in $\mathrm{Ni}_{2}$ (dobdc) at $77 \mathrm{~K}$. 


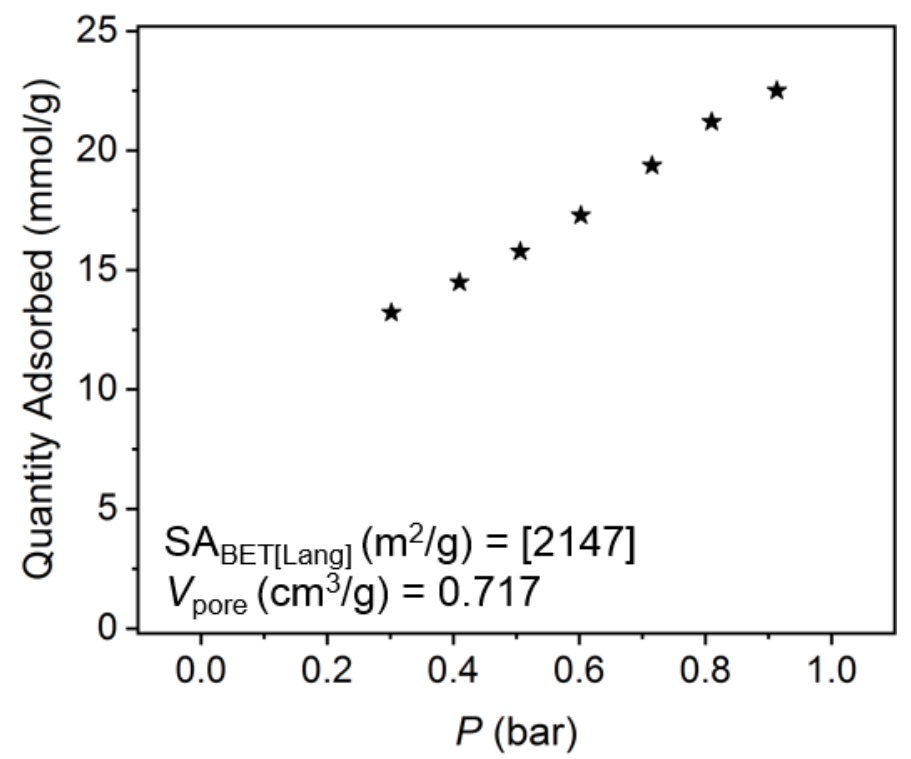

Figure S27. Adsorption of $\mathrm{N}_{2}$ in $\mathrm{Ni}_{2}$ (dobdc)-RT at $77 \mathrm{~K}$.

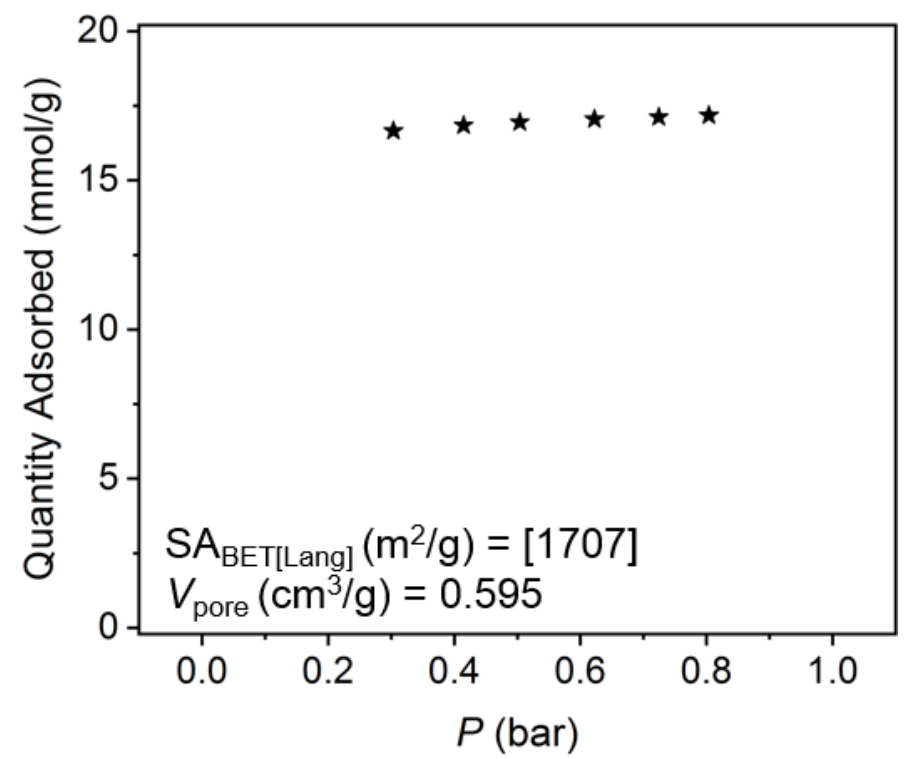

Figure S28. Adsorption of $\mathrm{N}_{2}$ in $\mathrm{Ni}(m-\mathrm{bdc})$ at $77 \mathrm{~K}$. 


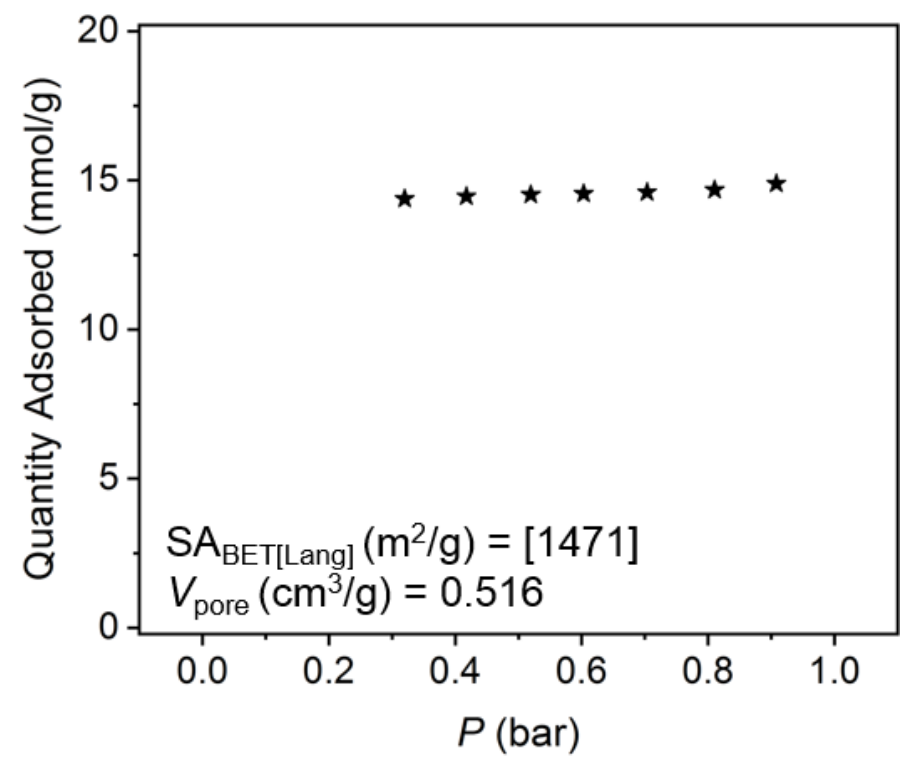

Figure S29. Adsorption of $\mathrm{N}_{2}$ in $\mathrm{Ni}_{2}(m-$ dobdc $)$ at $77 \mathrm{~K}$.

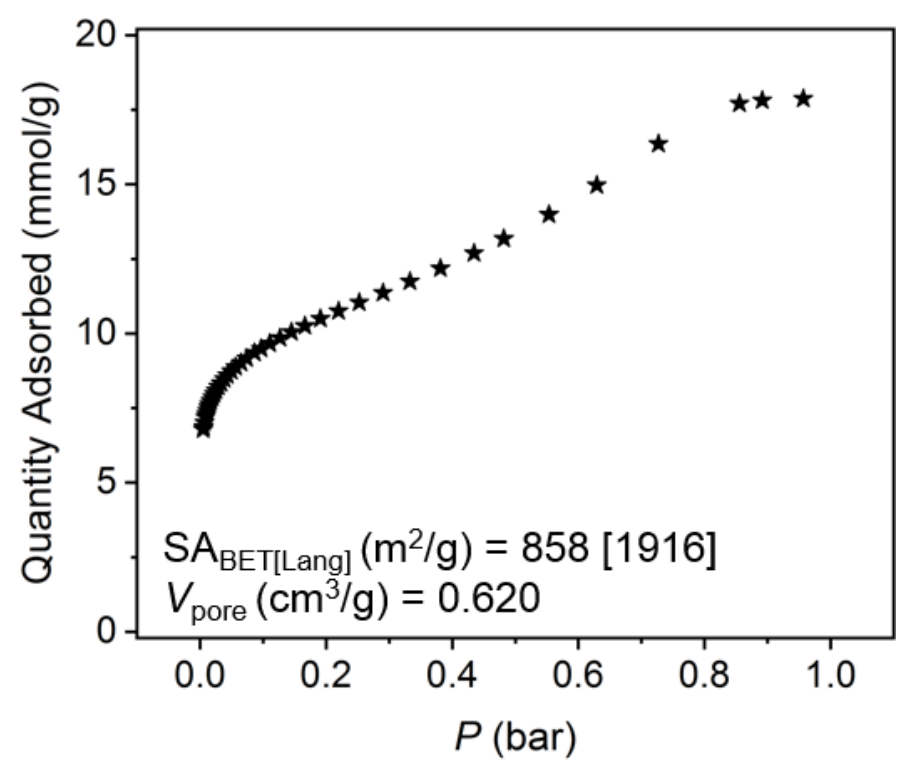

Figure S30. Adsorption of $\mathrm{N}_{2}$ in $\mathrm{Ni}_{2}(m$-dobdc)-RT at $77 \mathrm{~K}$. 


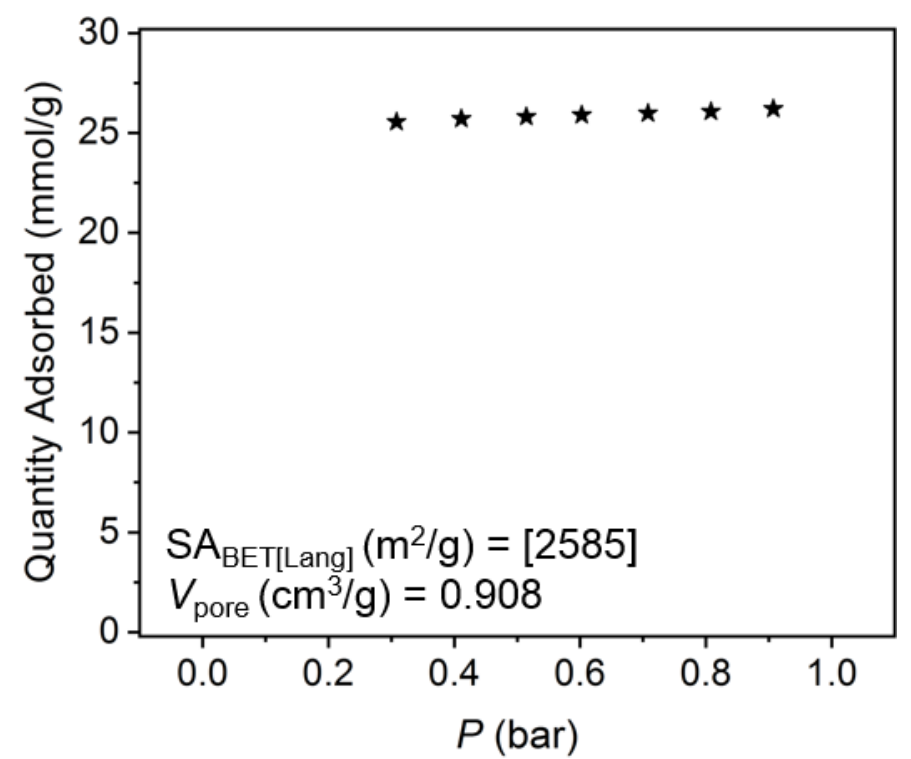

Figure S31. Adsorption of $\mathrm{N}_{2}$ in NOTT-101 at $77 \mathrm{~K}$.

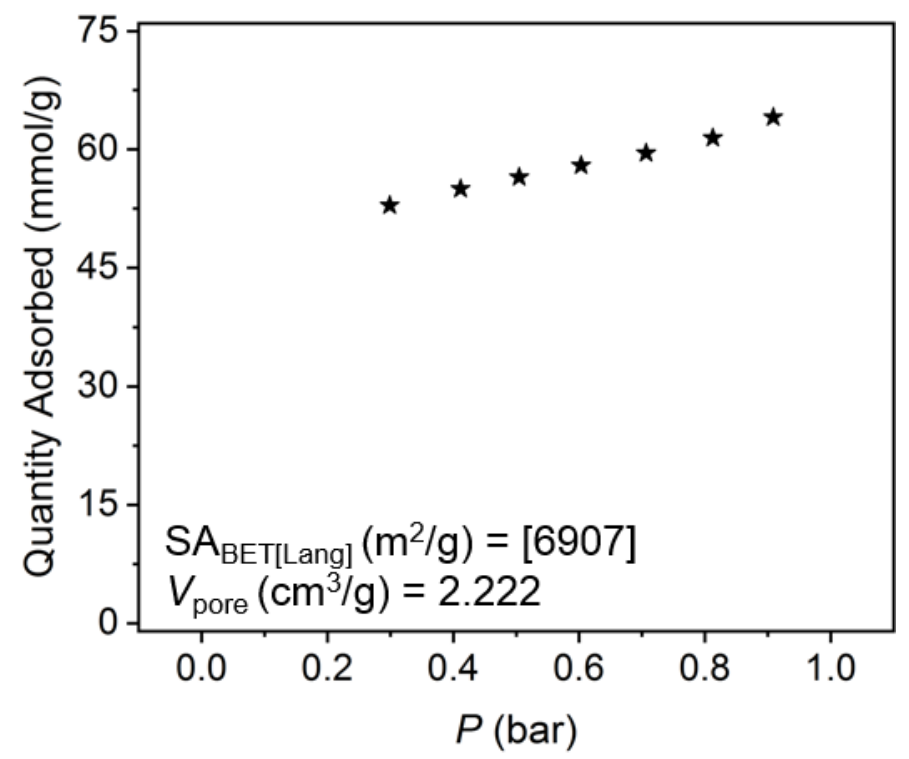

Figure S32. Adsorption of $\mathrm{N}_{2}$ in PAF-1 at $77 \mathrm{~K}$. 


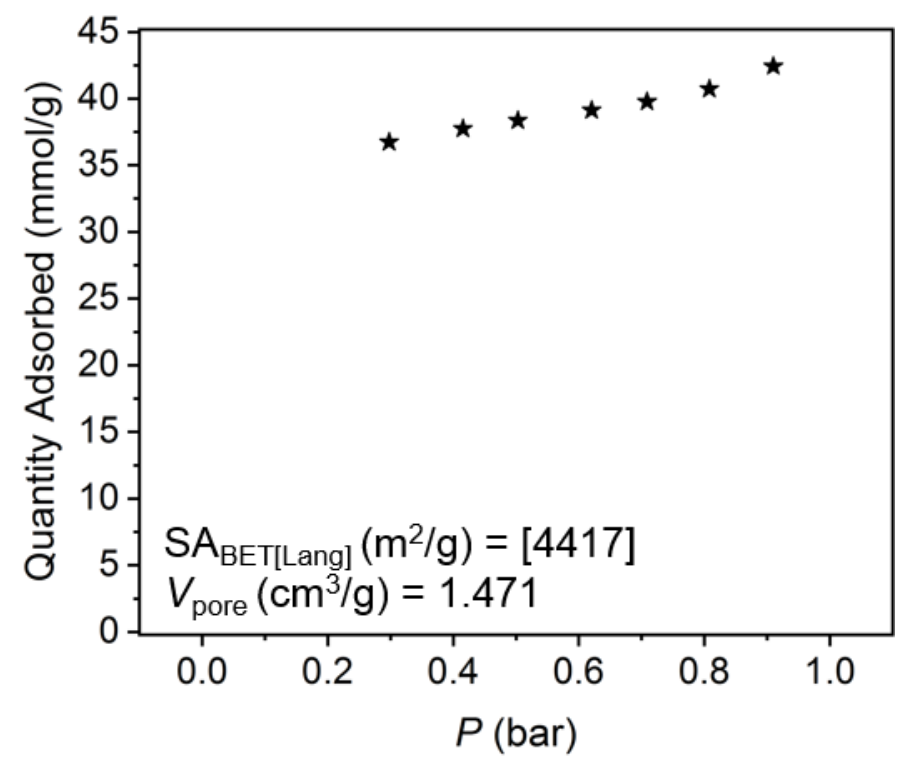

Figure S33. Adsorption of $\mathrm{N}_{2}$ in Ti-MIL-100 at $77 \mathrm{~K}$.

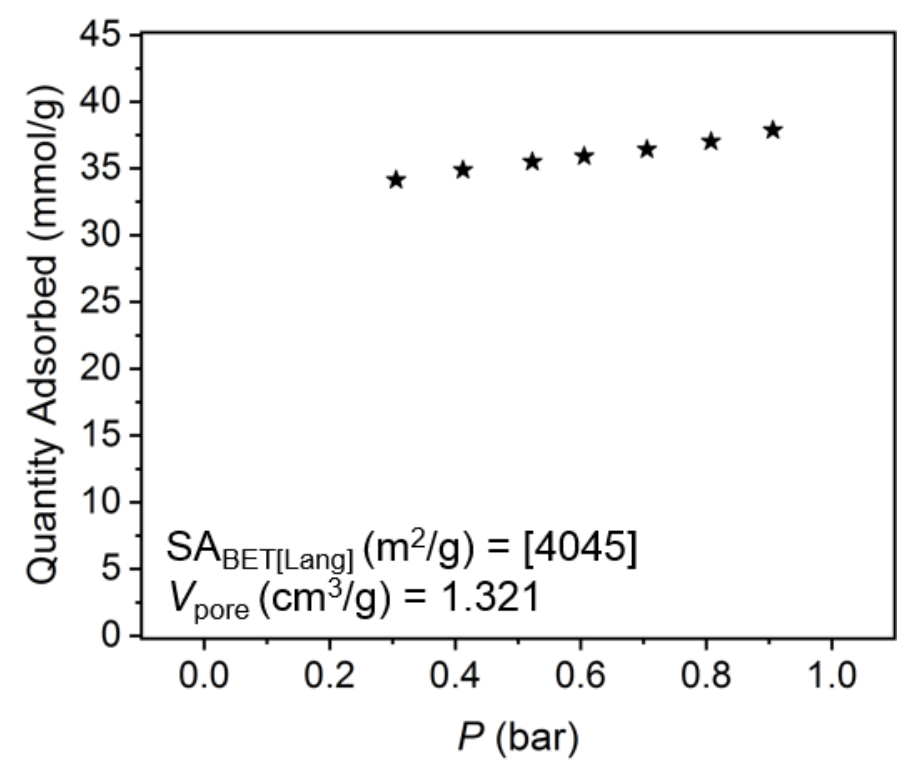

Figure S34. Adsorption of $\mathrm{N}_{2}$ in Ti-MIL-101 at $77 \mathrm{~K}$. 


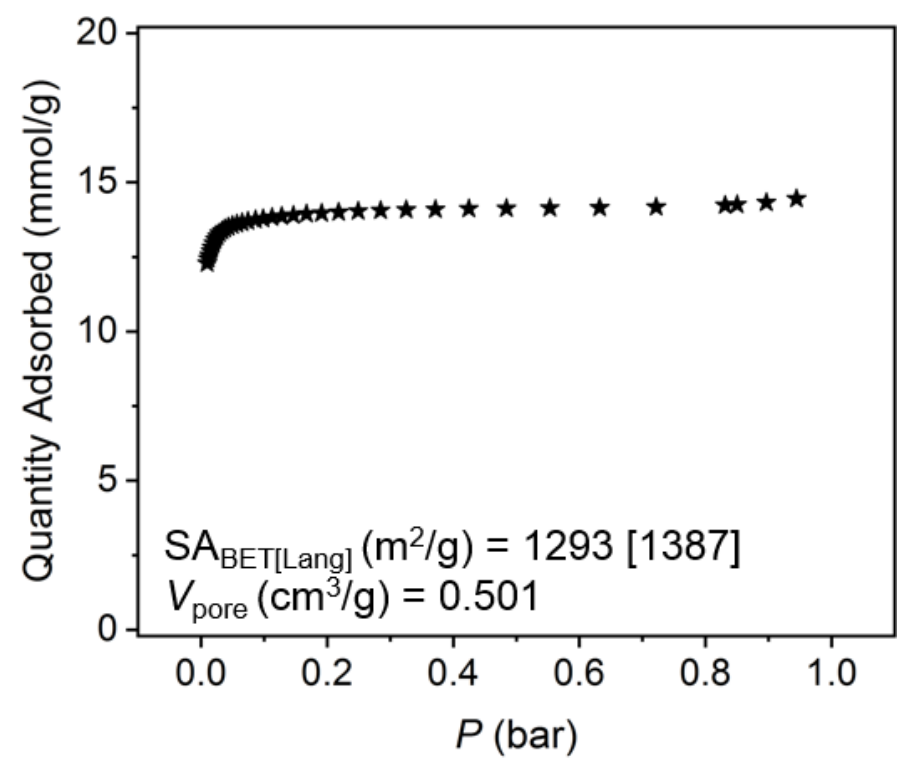

Figure S35. Adsorption of $\mathrm{N}_{2}$ in UiO-66 1 Ligand Missing $106.5 \mathrm{~nm}$ at $77 \mathrm{~K}$.

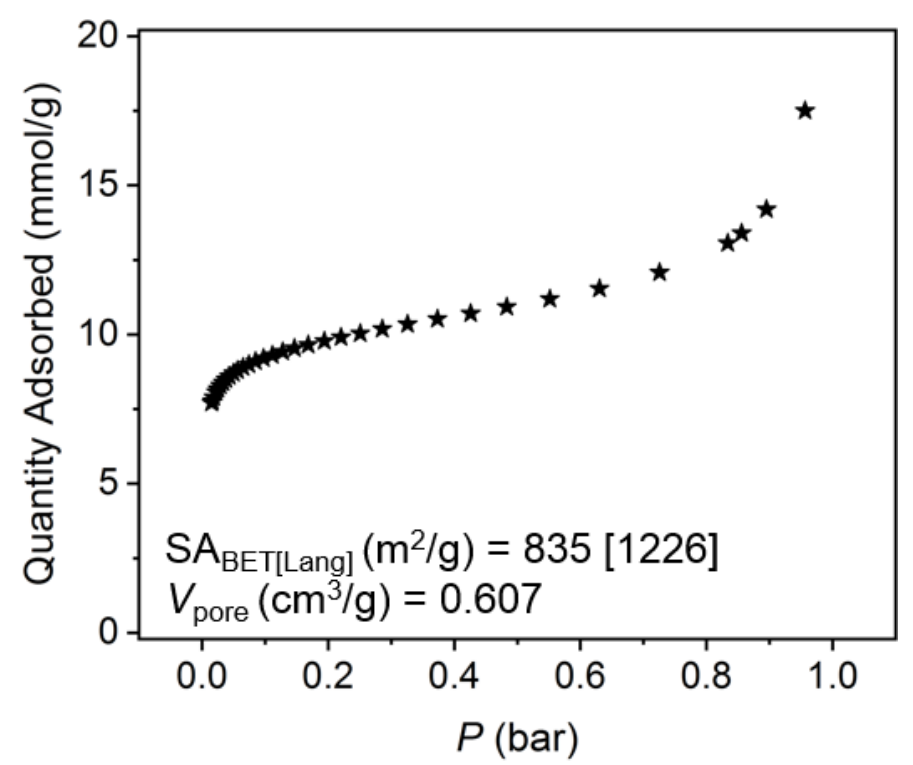

Figure S36. Adsorption of $\mathrm{N}_{2}$ in UiO-66 1 Ligand Missing $71.4 \mathrm{~nm}$ at $77 \mathrm{~K}$. 


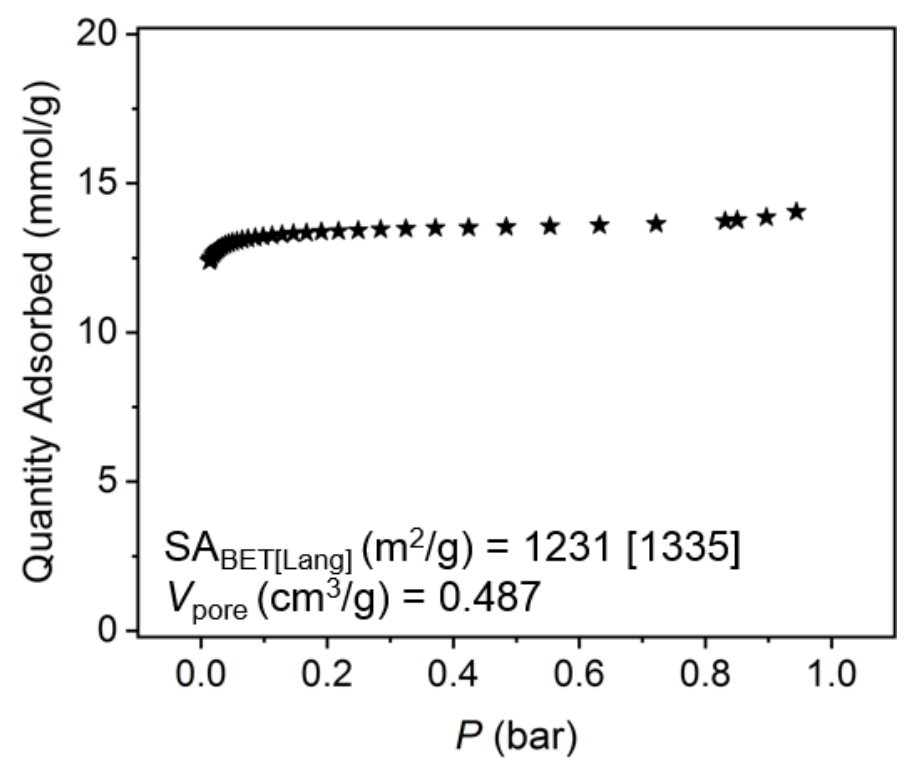

Figure S37. Adsorption of $\mathrm{N}_{2}$ in UiO-66 Defect Free $91.9 \mathrm{~nm}$ at $77 \mathrm{~K}$.

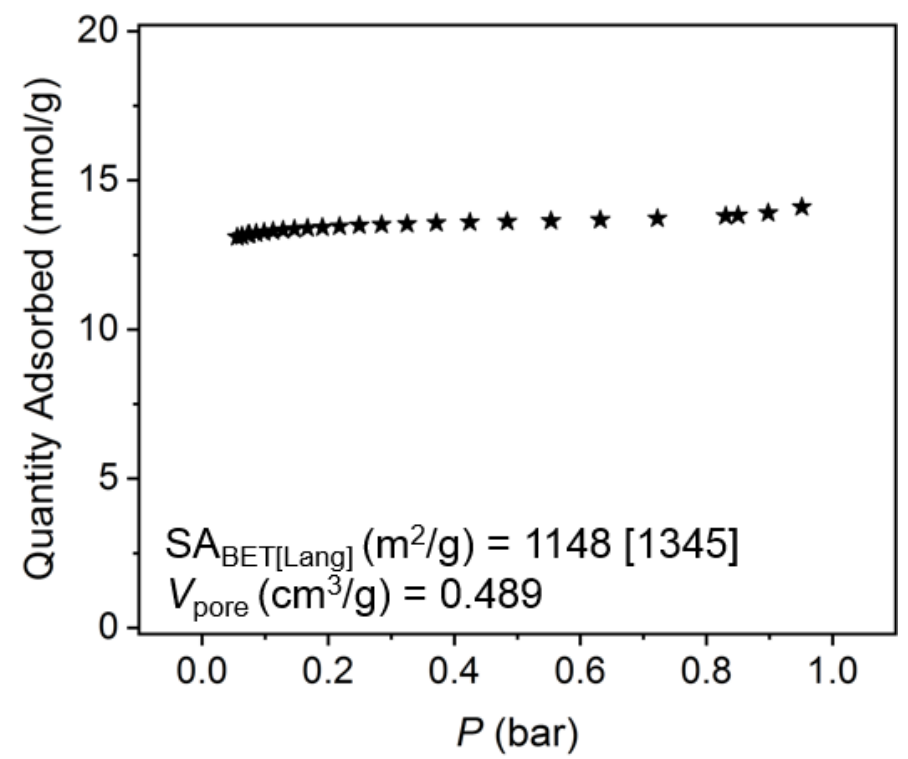

Figure S38. Adsorption of $\mathrm{N}_{2}$ in UiO-66 Defect Free $82.5 \mathrm{~nm}$ at $77 \mathrm{~K}$. 


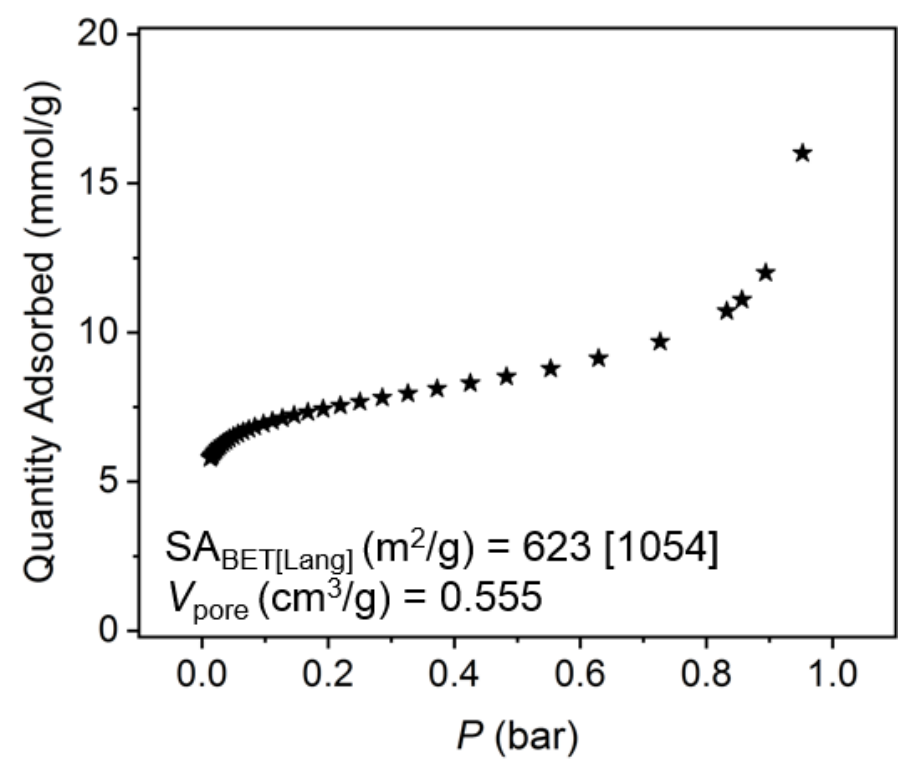

Figure S39. Adsorption of $\mathrm{N}_{2}$ in UiO-66 Defect Free $23.1 \mathrm{~nm}$ at $77 \mathrm{~K}$.

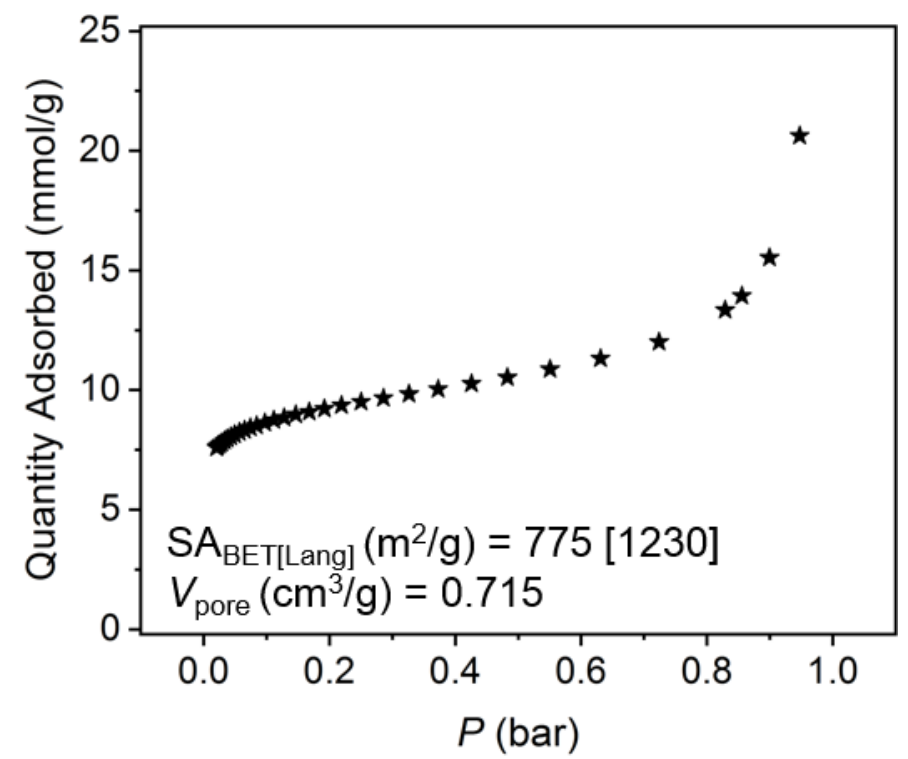

Figure S40. Adsorption of $\mathrm{N}_{2}$ in UiO-66 Defect Free $20.2 \mathrm{~nm}$ at $77 \mathrm{~K}$. 


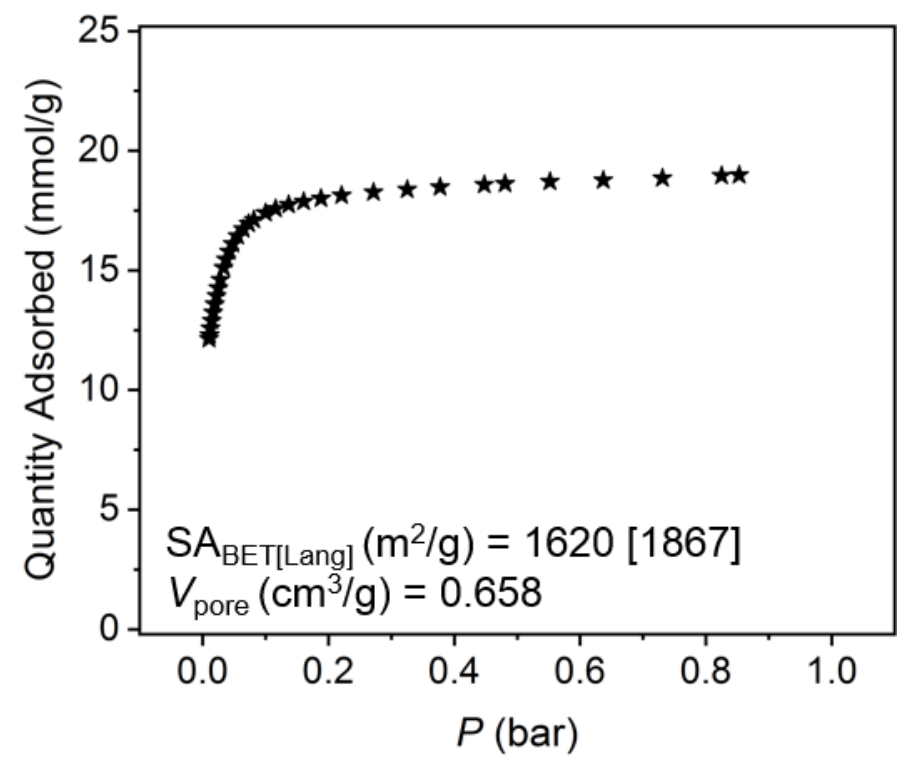

Figure S41. Adsorption of $\mathrm{N}_{2}$ in UiO-66 High SA at $77 \mathrm{~K}$.

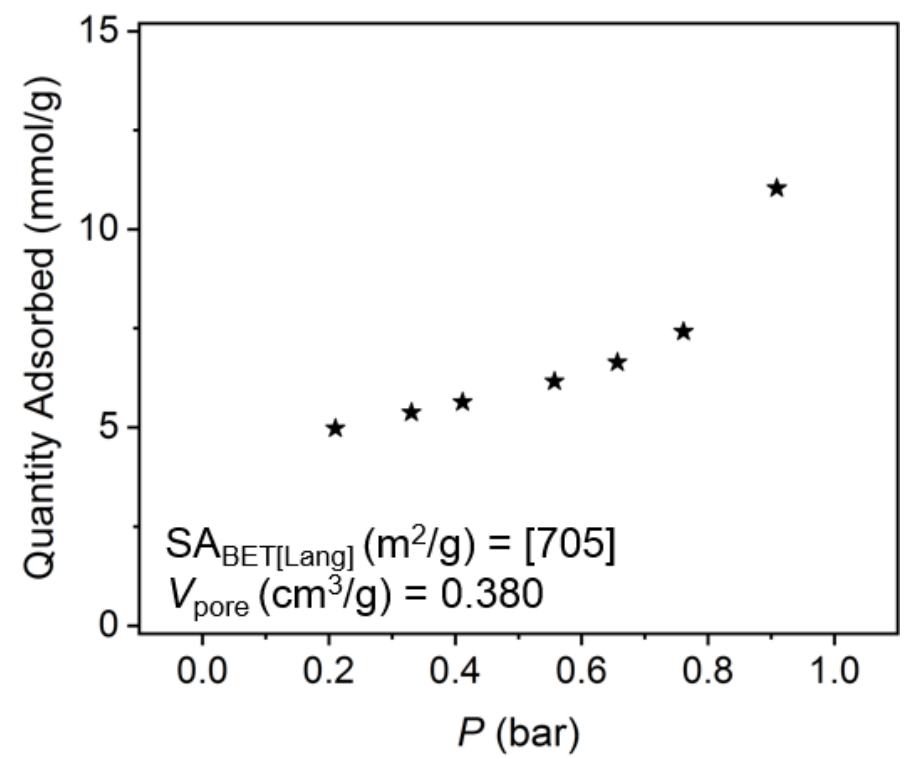

Figure S42. Adsorption of $\mathrm{N}_{2}$ in $\mathrm{UiO}-66-(\mathrm{COOH})_{2}$ at $77 \mathrm{~K}$. 


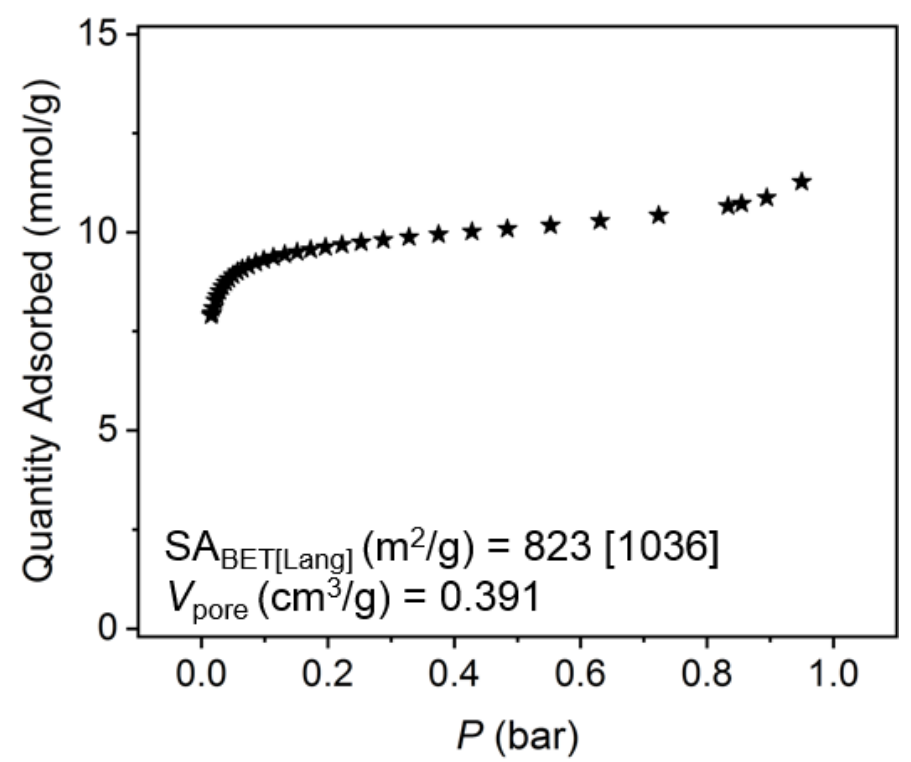

Figure S43. Adsorption of $\mathrm{N}_{2}$ in UiO-66-Acetyl at $77 \mathrm{~K}$.

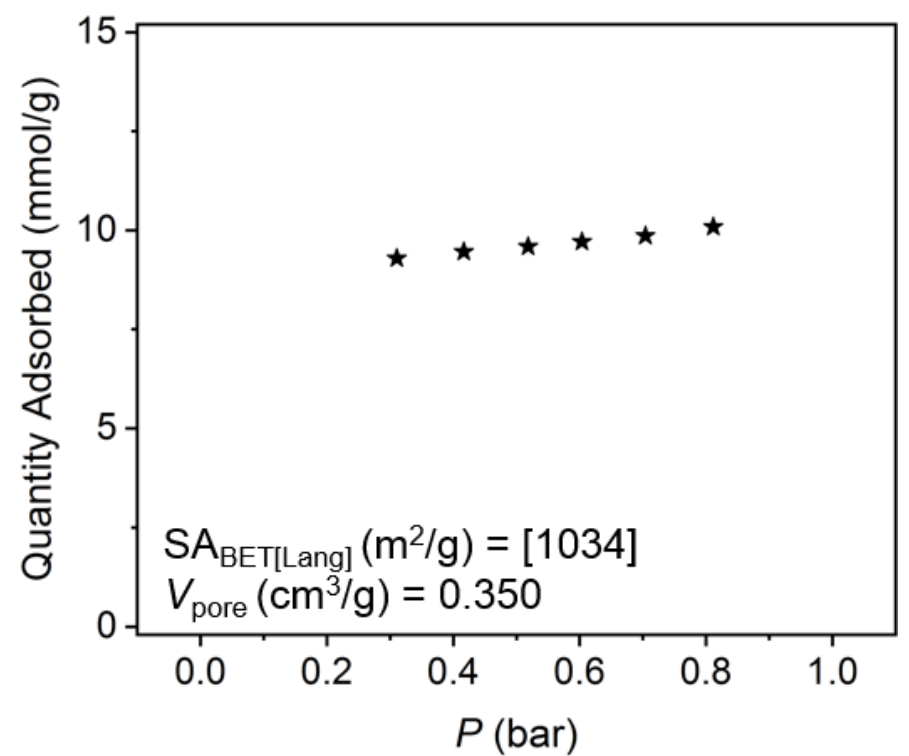

Figure S44. Adsorption of $\mathrm{N}_{2}$ in UiO-66-Butyrl at $77 \mathrm{~K}$. 




Figure S45. Adsorption of $\mathrm{N}_{2}$ in UiO-66- $\mathrm{NH}_{2}$ at $77 \mathrm{~K}$.

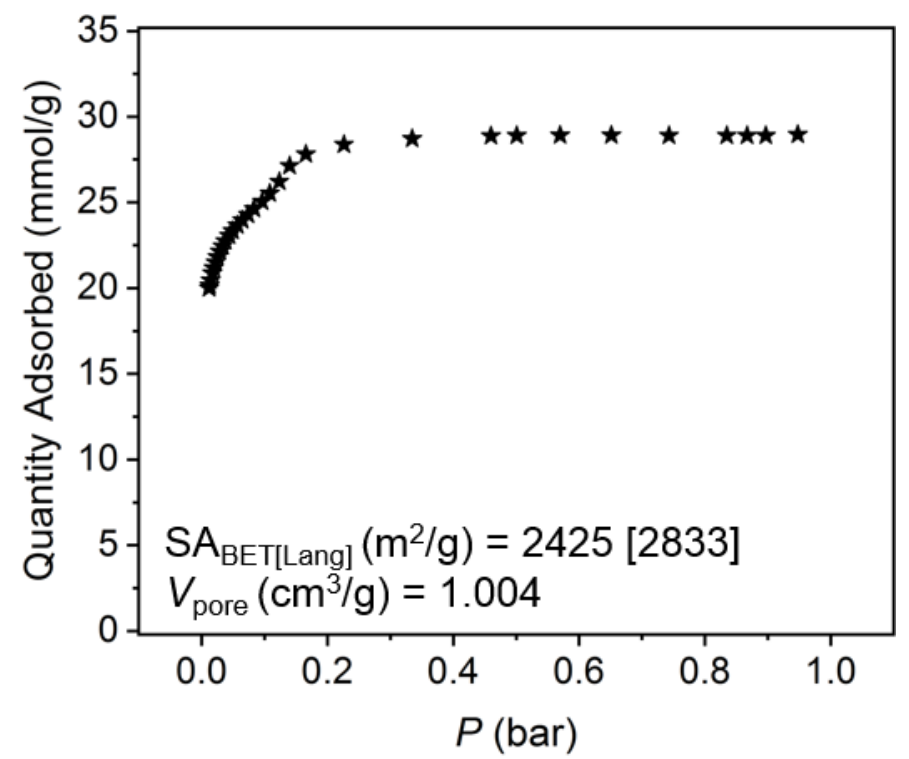

Figure S46. Adsorption of $\mathrm{N}_{2}$ in UiO-67 at $77 \mathrm{~K}$. 


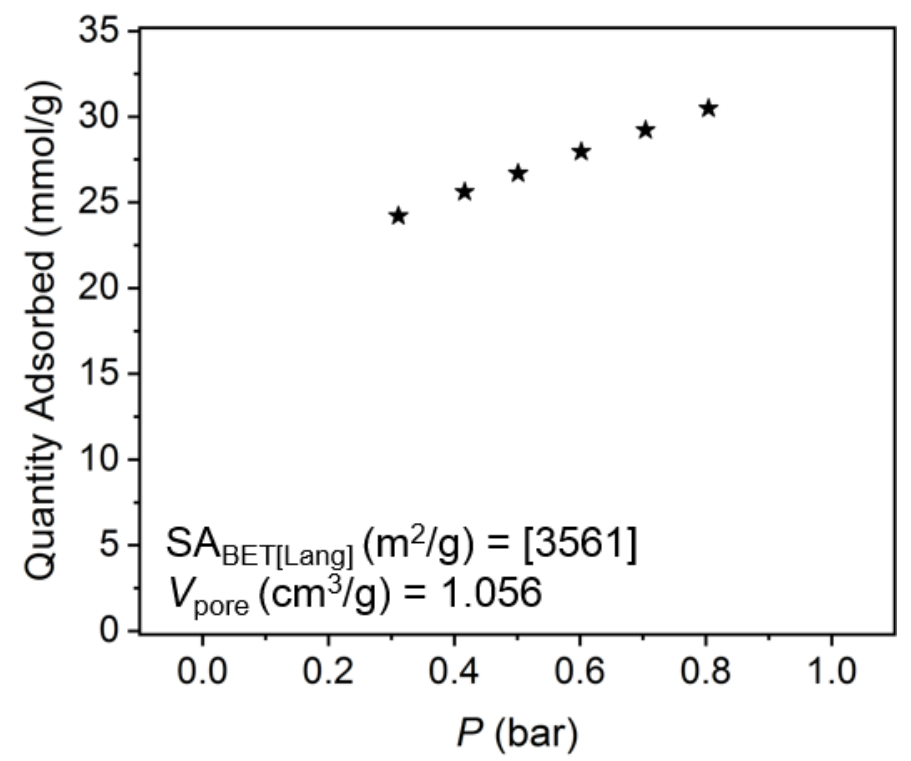

Figure S47. Adsorption of $\mathrm{N}_{2}$ in V-MIL-100 at $77 \mathrm{~K}$.

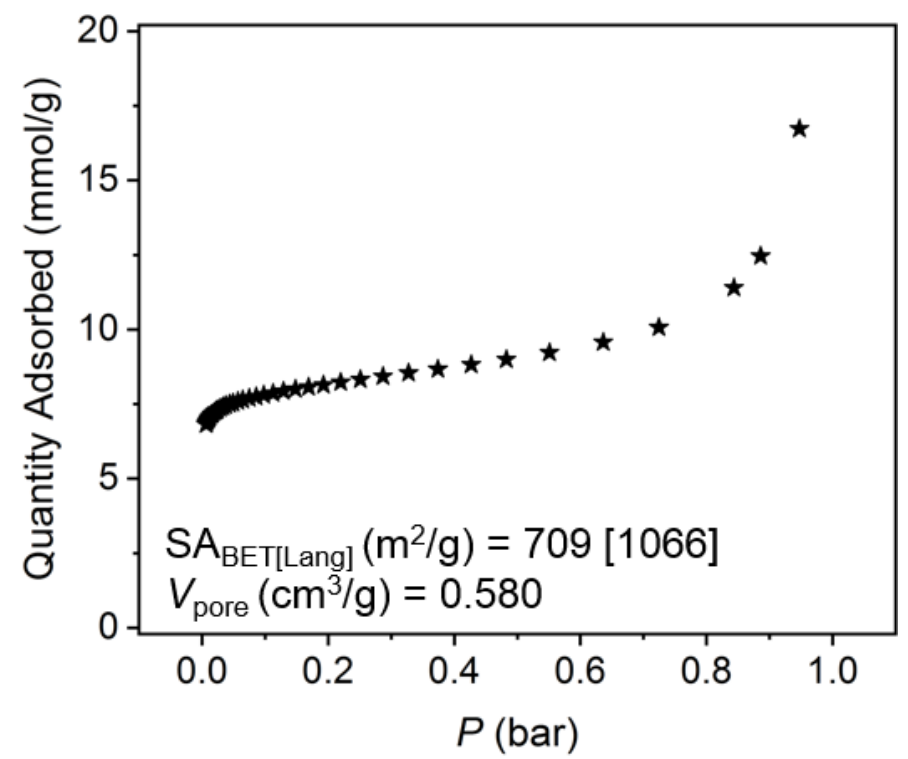

Figure S48. Adsorption of $\mathrm{N}_{2}$ in $\mathrm{Zn}_{2}$ (dobdc)-RT at $77 \mathrm{~K}$. 


\section{Defectiveness for Select UiO-66 Samples}

Table S1. Table of apparent density, ligand defectiveness, crystal density calculated from ligand defectiveness, and number of metal clusters missing required for the apparent density to match the calculated crystal density.

\begin{tabular}{|c|c|c|c|c|}
\hline Material & $\rho_{\mathrm{a}}\left(\mathrm{g} / \mathrm{cm}^{3}\right)$ & $\begin{array}{c}\text { Ligands missing per } \\
\text { formula unit }\end{array}$ & $\begin{array}{c}\rho_{\text {cryst }}\left(\mathrm{g} / \mathrm{cm}^{3}\right) \\
\text { calculated }\end{array}$ & $\begin{array}{c}\text { \# of metal clusters } \\
\text { missing }\end{array}$ \\
\hline Pristine & - & 0 & 1.246 & 0.000 \\
\hline High SA & 0.778 & 1.198 & 1.099 & 1.168 \\
\hline $\begin{array}{c}\text { UiO-66 1 } \\
\text { Ligand Missing } \\
106.5 \mathrm{~nm}\end{array}$ & 0.876 & 0.529 & 1.181 & 1.032 \\
\hline $\begin{array}{c}\text { UiO-66 1 } \\
\text { Ligand Missing } \\
71.4 \mathrm{~nm}\end{array}$ & 0.858 & 1.064 & 1.115 & 0.923 \\
\hline $\begin{array}{c}\text { UiO-66 } \\
\text { Defect Free } \\
91.9 \mathrm{~nm}\end{array}$ & 0.983 & 0.186 & 1.223 & 0.786 \\
\hline $\begin{array}{c}\text { UiO-66 } \\
\text { Defect Free } \\
82.5 \mathrm{~nm}\end{array}$ & 1.070 & 0.153 & 1.227 & 1.089 \\
\hline $\begin{array}{c}\text { UiO-66 } \\
\text { Defect Free } \\
23.1 \mathrm{~nm}\end{array}$ & 0.905 & 0.025 & 1.243 & 1.533 \\
\hline $\begin{array}{c}\text { UiO-66 } \\
\text { Defect Free } \\
20.2 \mathrm{~nm}\end{array}$ & 0.786 & -0.229 & 1.274 & \\
\hline
\end{tabular}


Table of Sample Densities

Table S2. List of all measured, skeletal densities, apparent densities and crystallographic densities for materials used in this study.

\begin{tabular}{|c|c|c|c|c|c|}
\hline Material & $\begin{array}{c}\rho_{\mathrm{sk}} \\
\left(\mathrm{g} / \mathrm{cm}^{3}\right)\end{array}$ & $\begin{array}{c}\rho_{a} \\
\left(\mathrm{~g} / \mathrm{cm}^{3}\right)\end{array}$ & $\begin{array}{c}\rho_{\text {cryst }} \\
\left(\mathrm{g} / \mathrm{cm}^{3}\right)\end{array}$ & $\begin{array}{l}\mathrm{BET} \\
\mathrm{m}^{2} / \mathrm{g}\end{array}$ & $\begin{array}{l}\text { Lang } \\
\mathrm{m}^{2} / \mathrm{g}\end{array}$ \\
\hline Al-MIL-101-NH ${ }_{2}$ & 1.798 & 0.781 & 0.440 & - & 2240 \\
\hline Al-MIL-53 & 1.573 & 0.929 & 0.978 & - & 1247 \\
\hline $\mathrm{Co}_{2}$ (dobdc) & 3.034 & 1.229 & 1.173 & - & 1362 \\
\hline $\mathrm{Co}_{2}$ (dobdc)-RT & 2.771 & 0.865 & 1.173 & - & 1657 \\
\hline $\mathrm{Co}_{2}(m$-dobdc $)$ & 2.987 & 1.188 & 1.188 & - & 1481 \\
\hline $\mathrm{Co}_{2}(m$-dobdc)-RT & 2.430 & 1.020 & 1.188 & - & 1396 \\
\hline $\mathrm{Co}_{2}(\mathrm{bdc})_{2}(\mathrm{dabco})$ & 1.716 & 0.772 & 0.815 & - & 2000 \\
\hline Cr-MIL-100 & 2.067 & 0.751 & 0.700 & - & 2473 \\
\hline Cr-MIL-101 & 1.662 & 0.501 & 0.440 & - & 3991 \\
\hline DUT-4 \#1 & 1.613 & 0.702 & 0.773 & - & 2398 \\
\hline DUT-4 \#2 & 1.566 & 0.720 & 0.773 & - & 2293 \\
\hline DUT-4 \#3 & 1.576 & 0.716 & 0.773 & - & 2257 \\
\hline Fe-MIL-100 & 2.168 & 0.796 & 0.700 & - & 2280 \\
\hline HKUST-1 (Korman) & 2.685 & 0.888 & 0.881 & - & 2141 \\
\hline HKUST-1 (Mason) & 2.637 & 0.895 & 0.881 & - & 2103 \\
\hline $\operatorname{Mg}_{2}(\mathrm{dobdc})$ & 2.125 & 0.856 & 0.909 & - & 1993 \\
\hline $\mathrm{Mg}_{2}$ (dobdc)-RT & 1.725 & 0.798 & 0.909 & 1190 & 1916 \\
\hline $\mathrm{Mg}_{2}(m$-dobdc)-RT & 1.587 & 0.518 & 0.924 & 1016 & 1960 \\
\hline MIL-125-NH & 1.839 & 0.930 & 0.810 & - & 1482 \\
\hline MIL-88A & 1.587 & 1.537 & 1.730 & - & 51 \\
\hline MIL-88C & 1.423 & 1.420 & 1.740 & - & 8 \\
\hline MOF-801 & 1.948 & 1.091 & 1.600 & - & 1197 \\
\hline MOF-808 & 2.535 & 0.853 & 0.860 & - & 2224 \\
\hline $\mathrm{Ni}_{2}$ (dobdc) & 2.871 & 1.128 & 1.195 & - & 1532 \\
\hline $\mathrm{Ni}_{2}$ (dobdc)-RT & 2.124 & 0.843 & 1.195 & - & 2147 \\
\hline $\mathrm{Ni}(m-\mathrm{bdc})$ & 1.584 & 0.815 & 0.732 & - & 1707 \\
\hline $\mathrm{Ni}_{2}(m$-dobdc $)$ & 3.293 & 1.220 & 1.200 & - & 1471 \\
\hline $\mathrm{Ni}_{2}(m$-dobdc)-RT & 2.235 & 0.937 & 1.200 & 858 & 1916 \\
\hline NOTT-101 & 2.465 & 0.761 & 0.684 & - & 2585 \\
\hline PAF-1 & 1.144 & 0.323 & - & - & 6907 \\
\hline Terephthalic Acid & 1.564 & - & 1.579 & - & 4417 \\
\hline Trimesic Acid & 1.465 & - & 1.449 & - & 4045 \\
\hline Ti-MIL-100 & 1.626 & 0.479 & 0.700 & & 4417 \\
\hline Ti-MIL-101 & 0.896 & 0.410 & 0.440 & & 4045 \\
\hline UiO-66 1 Ligand Missing $106.5 \mathrm{~nm}$ & 1.564 & 0.876 & 1.246 & 2393 & 1387 \\
\hline UiO-66 1 Ligand Missing 71.4 nm & 1.789 & 0.858 & 1.246 & 835 & 1226 \\
\hline UiO-66 Defect Free $91.9 \mathrm{~nm}$ & 1.886 & 0.983 & 1.246 & 1231 & 1335 \\
\hline UiO-66 Defect Free $82.5 \mathrm{~nm}$ & 2.242 & 1.070 & 1.246 & 1148 & 1345 \\
\hline UiO-66 Defect Free $23.1 \mathrm{~nm}$ & 1.815 & 0.905 & 1.246 & 623 & 1054 \\
\hline UiO-66 Defect Free $20.2 \mathrm{~nm}$ & 1.795 & 0.786 & 1.246 & 775 & 1230 \\
\hline UiO-66 High SA & 1.594 & 0.778 & 1.246 & 1620 & 1867 \\
\hline $\mathrm{UiO}-66-(\mathrm{COOH})_{2}$ & 2.717 & 1.337 & 1.642 & - & 705 \\
\hline UiO-66-Acetyl & 1.937 & 1.102 & 1.547 & 823 & 1036 \\
\hline UiO-66-Butyrl & 1.847 & 1.122 & 1.669 & - & 1034 \\
\hline $\mathrm{UiO}-66-\mathrm{NH}_{2}$ & 1.960 & 0.941 & 1.314 & 1296 & 1537 \\
\hline UiO-67 & 1.944 & 0.659 & 0.724 & 2425 & 2833 \\
\hline V-MIL-100 & 2.097 & 0.652 & 0.700 & - & 3561 \\
\hline $\mathrm{Zn}_{2}$ (dobdc)-RT & 2.838 & 1.073 & 1.231 & 709 & 1066 \\
\hline
\end{tabular}




\section{References}

1) Serra-Crespo, P.; Ramos-Fernandez, E. V.; Gascon, J.; Kapteijn, F. Synthesis and Characterization of an Amino Functionalized MIL-101(Al): Separation and Catalytic Properties. Chem. Mater. 2011, 23, 2565-2572.

2) Rallapalli, R.; Patil, D.; Prasanth, K. P.; Somani, R. S.; Jasra, R. V.; Bajaj, H. C. An Alternative Activation Method for the Enhancement of Methane Storage Capacity of Nanoporous Aluminum Terephthalate, MIL-53(AI). J. Porous Mater. 2010, 17, 523-528.

3) Mason, J. A.; Veenstra, M.; Long, J. R. Evaluating Metal-Organic Frameworks for Natural Gas Storage. Chem. Sci. 2014, 5, 32-51.

4) Bae, T.-H.; Long, J. R. $\mathrm{CO}_{2} / \mathrm{N}_{2}$ Separations with Mixed-Matrix Membranes Containing $\mathrm{Mg}_{2}$ (dobdc) Nanocrystals. Energy Environ. Sci. 2013, 6, 3565-3569

5) Kapelewski, M. T.; Runčevski, T.; Tarver, J. D.; Jiang, H. Z. H.; Hurst, K. E.; Parilla, P. A.; Ayala, A.; Gennett, T.; FitzGerald, S. A.; Brown, C. M.; Long, J. R. Record High Hydrogen Storage Capacity in the Metal-Organic Framework $\mathrm{Ni}_{2}$ (m-dobdc) at Near-Ambient Temperatures. Chem. Mater. 2018, 30, 8179-8189.

6) Wang, H.; Getzchmann, J.; Senkovska, I.; Kaskel, S. Structural Transformation and High Pressure Methane Adsorption of $\mathrm{Co}_{2}(1,4-\mathrm{bdc})_{2}$ dabco. Micropor. Mesopor. Mater. 2008, 116, 653-657.

7) Llew, P. L.; Bourrelly, S.; Serre, C.; Vimont, A.; Daturi, M.; Hamon, L.; Weireld, G. D.; Chang, J. S.; Hong, D. Y.; Hwang, Y. K.; Jhung, S. H.; Férey, G. High Uptakes of $\mathrm{CO}_{2}$ and $\mathrm{CH}_{4}$ in Mesoporous Metal-Organic Frameworks MIL-100 and MIL-101. Langmuir 2008, 24, 7245-7250.

8) Horcajada, P.; Serre, C.; Vallet-Regí, M.; Sebban, M.; Taulelle, F.; Férey. G. MetalOrganic Frameworks as Efficient Materials for Drug Delivery. Angew. Chem. Int. Ed. 2006, 45, 5974-5978.

9) Senkovska, I.; Hoffman, F.; Fröba, M.; Getzschmann, J.; Böhlmann, W.; Kaskel, $\mathrm{S}$. New Highly Porous Aluminum Based Metal-Organic Frameworks: $\mathrm{Al}(\mathrm{OH})(\mathrm{ndc})$ (ndc $=2,6$-napthalene dicarboxylate) and $\mathrm{Al}(\mathrm{OH})(\mathrm{bpdc})$ (bpdc $=4,4^{\prime}$-biphenyl dicarboxylate). Microporous and Mesoporous Materials, 2009, 122, 93-98.

10) Kim, A.-R.; Ahn, S.; Yoon, T.-U.; Notestein, J. M.; Farha, O. K.; Bae, Y.-S. Fast Cyclohexane Oxidation Under Mild Reaction Conditions Through a Controlled Creation of Redox-Active $\mathrm{Fe}(\mathrm{II} / \mathrm{III})$ Sites in a Metal-Organic Framework. ChemCatChem 2019, 11, 5650-5656.

11) Sun, L. B.; Li, J. R.; Park, J.; Zhou, H.-C. Cooperative Template-Directed Assembly of Mesoporous Metal-Organic Frameworks. J. Am. Chem. Soc. 2012, 134, 126129. 
12) Sohali, M.; Yun, Y.-N.; Lee, E.; Kim, S. K.; Cho, K.; Kim, J.-N.; Kim, T. W.; Moon, J.-H.; Kim, H. Synthesis of Highly Crystalline $\mathrm{NH}_{2}-\mathrm{MIL}-125$ (Ti) with S-Shaped Water Isotherms for Adsorption Heat Transformation. Cryst. Growth Des. 2017, $17,1208-1213$

13) Ramsahye, N. A.; Trung, T. K.; Scott, L.; Nouar, F.; Devic, T.; Horcajada, P.; Magnier, E.; David, O.; Serre, C.; Trens, P. Impact of the Flexible Character of MIL-88(III) Dicarboxylates on the Adsorption of $n$-Alkanes. Chem. Mater. 2013, 25, 479-488.

14) Furukawa, H.; Gándara, F.; Zhang, Y.-B.; Jiang, J.; Queen, W. L.; Hudson, M. R.; Yaghi, O. M. Water Adsorption in Porous Metal-Organic Frameworks and Related Materials. J. Am. Chem. Soc. 2014, 136, 4369-4381.

15) Gosselin, A. J.; Rowland, C. A.; Balto, K. P.; Yap, G. P. A.; Bloch, E. D. Design and Synthesis of Porous Nickel(II) and Cobalt (II) Cages. Inorg. Chem. 2018, 57, 11847-11850.

16) Lin, X.; Telepeni, I.; Blake, A. J.; Dailly, A.; Brown, C. M.; Simmons, J. M.; Zoppi, M.; Walker, G. S.; Thomas, K. M.; May, T. J.; Huvverstey, P.; Champness, N. R.; Schröder, M. High Capacity Hydrogen Adsorption in $\mathrm{Cu}(\mathrm{II})$ Tetracarboxylate Framework Materials: The Role of Pore Size, Ligand Functionalization, and Exposed Metal Sites. J. Am. Chem. Soc. 2009, 131, 2159-2171.

17) Ben, T.; Ren, H.; Ma, S.; Cao, D.; Lan, J.; Jing, X.; Wang, W.; Xu, J.; Deng, F.; Simmons, J. M.; Qiu, S.; Zhu, G. Target Synthesis of a Porous Aromatic Framework with High Stability and Exceptionally High Surface Area. Angew. Chem. Int. Ed. 2009, 48, 9457-9460.

18) Antonio, A. M.; Rosenthal, J.; Bloch, E. D. Electrochemically Mediated Syntheses of Titanium(III)-Based Metal-Organic Frameworks. J. Am. Chem. Soc. 2019, 141, 11383-11387.

19) Decker, G. E.; Stillman, Z.; Attia, L.; Fromen, C. A.; Bloch, E. D. Controlling Size, Defectiveness, and Fluorescence in Nanoparticle UiO-66 Through Water and Ligand Modulation. Chem. Mater. 2019, 31, 4831-4839.

20) Katz, M. J.; Brown, Z. J.; Colón, Y. J.; Siu, P. W.; Scheidt, K. A.; Snurr, R. Q.; Hupp, J. T.; Farha, O. K. A Facile Synthesis of UiO-66, UiO-67 and Their Derivatives. Chem. Commun. 2013, 49, 9449-9451.

21) Ragon, F.; Campo, B.; Yang, Q.; Martineau, C.; Wiersum, A. D.; Lago, A.; Guillerm, V.; Hemsley, C.; Eubank, J. F.; Vishnuvarthan, M.; Taulelle, F.; Horcajada, P.; Vimont, A.; Llewellyn, P. L.; Daturi, M.; Devautour-Vinot, S.; Maurin, G.; Serre, C.; Devic, T.; Clet, G. Acid-Functionalized UiO-66(Zr) MOFs and their Evolution After Intra-Framework Cross-Linking: Structural Features and Sorption Properties. J. Mater. Chem. A 2015, 3, 3294-3309. 
22) Lieb, A.; Leclerc, H.; Devic, T.; Serre, C.; Margiolaki, I.; Mahjoubi, F.; Lee, J. S.; Vimont, A.; Daturi, M.; Chang, J.-S. MIL-100(V) - A Mesoporous Vanadium MetalOrganic Framework with Accessible Metal Sites. Microporous and Mesoporous Materials 2012, 157, 18-23. 